\title{
Taphonomic experiments imply a possible link between the evolution of multicellularity and the fossilization potential of soft-bodied organisms
}

\author{
Elena Naimark ${ }^{1}$, Dmitry Kirpotin ${ }^{2}$, Natalia Boeva ${ }^{3}$, Vladimir Gmoshinskiy ${ }^{4}$, Maria \\ Kalinina $^{5}$, Yulia Lyupina ${ }^{6}$, Alexander Markov ${ }^{7}$, Michail Nikitin $^{8}$, Alexander Shokurov ${ }^{5}$ \\ and Dmitry Volkov ${ }^{4}$ \\ ${ }^{1}$ Borissiak Paleontological Institute of the Russian Academy of Sciences \\ ${ }^{2}$ Kirpotin Biotechnology Consulting \\ ${ }^{3}$ Institute of Geology of Ore Deposits Petrography Mineralogy and Geochemistry RAS \\ ${ }^{4}$ Lomonosov Moscow State University \\ ${ }^{5}$ Frumkin Institute of Physical Chemistry and Electrochemistry RAS \\ ${ }^{6}$ Koltzov Institute of Development Biology RAS \\ ${ }^{7}$ Moscow State University \\ ${ }^{8}$ Lomonosov Moscow State University A N Belozersky Institute of Physico-Chemical \\ Biology
}

July 27, 2020

\begin{abstract}
The reliability of evolutionary reconstructions based on the fossil record critically depends on our knowledge of the factors affecting the fossilization of soft-bodied organisms. Despite considerable research effort, these factors are still poorly understood. The extreme rarity of unicellular non-skeletal eukaryotic fossils compared to multicellular ones is an example of a pattern that apparently requires taphonomic explanation. In order to elucidate the main prerequisites for the preservation of soft-bodied organisms, we conducted long-term (1-5 years) taphonomic experiments with the model crustacean Artemia salina buried in five different sediments. The subsequent analysis of the carcasses and sediments revealed that, in our experimental settings, better preservation was associated with the fast deposition of aluminium and silicon on organic tissues. Other elements such as calcium, magnesium and iron, which can also accumulate quickly on the carcasses, appear to be much less efficient in preventing decay. Next, we asked if the carcasses of uni- and multicellular organisms differ in their ability to accumulate aluminium ions on their surface. The experiments with the flagellate Euglena gracilis and the sponge Spongilla lacustris showed that aluminium ions are more readily deposited onto a multicellular body. This was further confirmed by the experiments with uni- and multicellular stages of the social amoeba Dictyostelium discoideum. The results lead us to speculate that the evolution of cell adhesion molecules, which provide efficient cell-cell and cell-substrate binding, probably can explain the rich fossil record of multicellular soft-bodied organisms, the poor fossil record of non-skeletal unicellular eukaryotes, and the explosive emergence of the Cambrian diversity of soft bodied fossils.
\end{abstract}

Taphonomic experiments imply a possible link between the evolution of multicellularity and the fossilization potential of soft-bodied organisms

Short title / Running head: Multicellularity and fossilization of soft tissues

Elena Naimark ${ }^{1^{*}}$, Dmitry Kirpotin ${ }^{2 *}$, Natalia Boeva ${ }^{3}$, Vladimir Gmoshinskiy ${ }^{4}$, Maria 
Kalinina $^{5}$, Yulia Lyupina ${ }^{6}$, Alexander Markov ${ }^{1,4}$, Michail Nikitin ${ }^{7,8,9}$, Alexander Shokurov ${ }^{5}$, Dmitry Volkov ${ }^{10}$

${ }^{1}$ Borissiak Paleontological Institute, Russian Academy of Sciences, 117559, Russia

${ }^{2}$ Kirpotin Biotechnology Consulting, San Francisco, CA, 94121, USA

${ }^{3}$ Institute of Geology of Ore Deposits, Petrography, Mineralogy, and Geochemistry, Russian Academy of Sciences, Moscow, 119017, Russia

${ }^{4}$ Faculty of Biology, Moscow State University, Moscow, 119991, Russia

${ }^{5}$ Frumkin Institute of Physical Chemistry and Electrochemistry, Russian Academy of Sciences, Moscow, 119071, Russia

${ }^{6}$ Koltzov Institute of Developmental Biology, Russian Academy of Sciences, Moscow, 119334, Russia

${ }^{7}$ Belozersky Institute for Physico-Chemical Biology, Moscow State University, Moscow, 119991, Russia

${ }^{8}$ Kharkevich Institute for Information Transmission Problems, Russian Academy of Sciences, Moscow, 127051, Russia

${ }^{9}$ Institute of Biology of the Southern Seas, Russian Academy of Sciences, Moscow, 119991, Russia

${ }^{10}$ Faculty of Chemistry, Moscow State University, , Moscow, 119991, Russia

*Corresponding authors: Elena Naimark, Dmitry Kirpotin.

Email: naimark_e@mail.ru,dkirpo@earthlink.net

The reliability of evolutionary reconstructions based on the fossil record critically depends on our knowledge of the factors affecting the fossilization of soft-bodied organisms. Despite considerable research effort, these factors are still poorly understood. The extreme rarity of unicellular non-skeletal eukaryotic fossils compared to multicellular ones is an example of a pattern that apparently requires taphonomic explanation. In order to elucidate the main prerequisites for the preservation of soft-bodied organisms, we conducted long-term (1-5 years) taphonomic experiments with the model crustacean Artemia salina buried in five different sediments. The subsequent analysis of the carcasses and sediments revealed that, in our experimental settings, better preservation was associated with the fast deposition of aluminium and silicon on organic tissues. Other elements such as calcium, magnesium and iron, which can also accumulate quickly on the carcasses, appear to be much less efficient in preventing decay. Next, we asked if the carcasses of uni- and multicellular organisms differ in their ability to accumulate aluminium ions on their surface. The experiments with the flagellate Euglena gracilis and the sponge Spongilla lacustris showed that aluminium ions are more readily deposited onto a multicellular body. This was further confirmed by the experiments with uni- and multicellular stages of the social amoeba Dictyostelium discoideum. The results lead us to speculate that the evolution of cell adhesion molecules, which provide efficient cell-cell and cell-substrate binding, probably can explain the rich fossil record of multicellular soft-bodied organisms, the poor fossil record of non-skeletal unicellular eukaryotes, and the explosive emergence of the Cambrian diversity of soft bodied fossils.

Key words : fossilization, soft bodied fossils, sediment, multicellularity, Metazoa, cell adhesion molecules.

\section{INTRODUCTION}

How can a soft-bodied organism escape decomposition and turn into a fossil? This question is crucial for understanding the patterns in the fossil record, such as the fast growth of the observed diversity of metazoans during the Cambrian including soft bodied organisms found in Lagerstätten. Many hypotheses have been suggested to explain the fossilization of soft-bodied organisms (SBO), as well as different modes of their 
preservation, by various abiotic and biotic factors. Abiotic factors that presumably enhance SBO preservation include low oxygenation (Allison, 1988; McCoy et al., 2015a, b; Naimark et al., 2016a, b), low or high acidity induced by decay (Berner, 1968; Allison, 1988; Briggs, Kear, 1997; Sagemann et al., 1999; Wilson, Butterfield, 2014; Naimark et al., 2016b), deposition of iron (Petrovich, 2001; Schiffbauer et al., 2014), phosphorus (Raff et al., 2008), calcium (Butterfield, 2003), silicon (Strang et al., 2016), or "tanning" by aluminium (Wilson, Butterfield, 2014; Naimark et al., 2016a, b, 2018a). Biotic factors include the lack of bioturbation and detritus consumers (Garson et al., 2011; but see: Pratt, Kimmig, 2019), the slow proliferation of sulfate reducers due to the depletion of sulfur and iron caused by early surface cementation (Hammarlund et al., 2011; Gaines et al., 2012; McCoy et al., 2015b), inhibition of bacterial growth and absorption of bacterial lytic enzymes by some clays (Butterfield, 1995; Kompantseva et al., 2011; McMahon et al., 2016), or otherwise, increased activity of cyanobacteria (or other bacteria) producing a mineral "death mask" (Gehling, 1999; Martin et al., 2004; Darroch et al., 2012; Raff et al., 2013). Such a wide variety of hypotheses reflects the fact that SBO can be fossilized in many different paleoenvironments, and many environmental factors can possibly affect the fossilization potential of SBO.

We asked (1) if there are some core processes among this wide variety that underpin the preservation of SBO, and (2) whether these processes differ between uni- and multicellular organisms. The latter question stems from the extreme rarity of soft-bodied unicellular eukaryotic fossils, whereas the Ediacaran and Phanerozoic fossil record of multicellular SBO is much more rich and diverse.

In order to identify core chemical pathways in SBO fossilization, we conducted a line of long term taphonomic experiments $(1,5-5$ years: the longest of this type) with the model multicellular organismArtemia salina buried in different sediments. Some results were published previously (Naimark et al., 2016a, b, 2018a, b, c). They are combined with the new ones presented here (Table 1). The results reveal coordinated changes in $\mathrm{pH}$ and mineral composition of the sediments, as well as in the elemental and chemical composition of the carcasses. These changes appear to be different facets of the complex preservational process in sediment. Overall, the results imply that the early deposition of aluminium and/or silica ions on decaying tissues significantly enhances SBO preservation.

Based on these results, we asked if the early deposition of aluminium proceeds differently on the surface of uni- and multicellular organisms. We used the flagellate Euglena gracilis and the spongeSpongilla lacustris as model systems in these experiments. We also experimented with the unicellular and multicellular stages of the colonial amoebae Dictyostelium discoideum. In all cases we found enhanced deposition of aluminium ions in multicellular organisms/stages compared to unicellular ones. It is noteworthy that the transition from unicellular to multicellular stage in D. discoideum is accompanied by the appearance of "intercellular glue", that is, by the expression of cell adhesion molecules (CAMs). The results led us to speculate that the emergence of CAMs at the early stages of the evolution of multicellularity might explain why the fossil records of unicellular and multicellular soft-bodied organisms are so dramatically different in richness.

\section{MATERIALS AND METHODS}

\subsection{Sediments used in taphonomic experiments with Artemia salina.}

We buried A. salina in five different fine-grained sediments (four clays and artificial silica) in order to assess the relative importance of different components and properties of the sediment for the preservation of SBO. Sediments of similar mineralogy are common in Lagerstätten (Anderson et al., 2018). However, we made no attempt to model real sediment types involved in Lagerstätten formation; rather, we sought to better understand the general principles of SBO fossilization. The main criterion for choosing sediments was the purity of the available samples which was crucial for the subsequent analysis and interpretation.

The initial chemical composition of the sediments, measured by X-ray fluorescent analysis, is shown in Table 2. The kaolin came from the Polog deposit (Ukraine) and contained $97 \%$ of kaolinite in the purified sample (see Naimark et al., 2016a for details). The clinochlore originated from the Akhmetievskoe deposit (Ural mountains) and was given to us from the collection of Fersman Mineralogical Museum (Moscow). The chamosite originated from the Kursk Magnetic Anomaly, the collection stored in the museum of the Institute 
of Geology of Ore Deposits, Petrography, Mineralogy and Geochemistry (Moscow). The montmorillonite was from Tikhmenievskoe deposit (Sakhalin), from the collection of one of the authors (N.B.). Artificial silica was precipitated from perlite by thermal decomposition $\left(150^{\circ} \mathrm{C}\right)$ with $\mathrm{NaOH}$ and consequent neutralization by sulfuric acid yielding porous, amorphous siliceous particles. We did not use glass beads or sand as a model for siliceous sediment (like in Newman et al., 2019) because glass beads and sand are chemically highly inert.

Non-sterile artificial sea water (ASW; brand "Tetra") was prepared according to the instructions for this brand. We checked its pH (7.4-7.8) and salinity (24X-ray fluorescent analysis (Table 2). For the freshwater experiment with montmorillonite we took tap water and kept it open under non-sterile conditions in a glass jar for a week to obtain a stable microbial consortium.

To prepare the sediments, all samples of minerals were ground finely in an agate mortar. Next, they were mixed in settled tap water and equilibrated for half a minute, allowing large and/or heavy particles to gravitate to the bottom. Then the upper portion (approximately $2 / 3$ of the suspension) was decanted. This upper portion was dried, ground again and mixed in ASW (or tap water in the case of montmorillonite) in proportion of $3 \mathrm{~g} / 100 \mathrm{ml}$. The resulting suspensions were actively mixed with bubbling from an air pump for 48 hours to remove clay pellets.

\subsection{Model organisms.}

We used nauplii L1 and L2 of Artemia salina (Branchiopoda, Crustacea) for the burial experiments. This model organism is suitable for our purposes because small crustacean fossils are found in many Lagerstatten, and also because its bright orange coloration helps to find the carcasses in the sediment. The nauplii were obtained from eggs after 36-48 hours of incubation and killed by keeping in fresh water for 4-6 hours.

For the experiments with the deposition of aluminium, we used unicellular and primitive multicellular model organisms: freshwater sponge Spongilla lacustris (Demospongiae, Porifera), flagellateEuglena gracilis (Euglenozoa, Excavata) and social amoebaDictyostelium discoideum (Amoebozoa). S. lacustris was collected in summer 2018 from Moskva river (Zvenigorodskaya biological station, Russia) and kept as a cryopreserved viable specimen. E. gracilis was cultured at the Faculty of Biology, Moscow State University, on the KramerMayer medium $\left(1 \mathrm{~g} / \mathrm{L}\left(\mathrm{NH}_{4}\right)_{2} \mathrm{HPO}_{4}, 1 \mathrm{~g} / \mathrm{L} \mathrm{KH}_{2} \mathrm{PO}_{4}, 0.8 \mathrm{~g} / \mathrm{L} \mathrm{Na}_{2} \mathrm{C}_{6} \mathrm{H}_{5} \mathrm{O}_{7} \times 5 \mathrm{H}_{2} \mathrm{O}, 0.2 \mathrm{~g} / \mathrm{L} \mathrm{MgSO} 4,0.02 \mathrm{~g} / \mathrm{L}\right.$ $\mathrm{CaCl}_{2}, 3 \mathrm{mg} / \mathrm{L} \mathrm{Fe}_{2}\left(\mathrm{SO}_{4}\right)_{3} \times \mathrm{xH}_{2} \mathrm{O}, 1.8 \mathrm{mg} / \mathrm{L} \mathrm{MnCl}_{2} \times 4 \mathrm{H}_{2} \mathrm{O}, 1.3 \mathrm{mg} / \mathrm{L} \mathrm{CoCl}_{2} \times 6 \mathrm{H}_{2} \mathrm{O}, 0.4 \mathrm{mg} / \mathrm{L} \mathrm{ZnSO}_{4} \times 7 \mathrm{H}_{2} \mathrm{O}$, $0.2 \mathrm{mg} / \mathrm{L} \mathrm{Na}_{3} \mathrm{Mo}_{4} \times 2 \mathrm{H}_{2} \mathrm{O}, 0.02 \mathrm{mg} / \mathrm{L} \mathrm{CuSO}_{4} \times 5 \mathrm{H}_{2} \mathrm{O}, 20 \mu \mathrm{g} / \mathrm{L}$ thiamine, $10 \mu \mathrm{g} / \mathrm{L}$ cobalamine, etanol to $0.2 \mathrm{M}$; pH 6.6-6.7). D. discoideum strain DBS0237637 from Dicty Stock Center (Northwestern University, Chicago, IL, USA) was grown on E.coli lawn on agar plates with SM5 medium (2 g/L glucose, $2 \mathrm{~g} / \mathrm{L}$ Bacto Peptone (Oxoid), $2 \mathrm{~g} / \mathrm{L}$ yeast extract (Oxoid), $0.2 \mathrm{~g} / \mathrm{L} \mathrm{MgCl}_{2}, 1.9 \mathrm{~g} / \mathrm{L} \mathrm{KHPO}_{4}, 1 \mathrm{~g} / \mathrm{L} \mathrm{K}_{2} \mathrm{HPO}_{4}, 15 \mathrm{~g} / \mathrm{L}$ agar). Before the experiments, Spongilla and Euglena were killed by freezing in liquid nitrogen, and D. discoideum by keeping in $500 \mu \mathrm{M} / \mathrm{L}$ sodium azide for 15 minutes (Sadiq, 1995).

\subsection{Design of the taphonomic (burial) experiments.}

Our taphonomic experiments (Table 1) imitate rapid burial of SBO under a sediment layer, which is believed to be a common condition for the Cambrian Lagerstätten formation. The experimental design was described in our earlier works (Naimark et al., 2016a, b, 2018 a, b). The homogeneously mixed clay suspensions were poured into high glass tubes $(50-70 \mathrm{~cm}$ in height, $1.0-1.5 \mathrm{~cm}$ in diameter; as we observed in multiple experiments, this variation did not affect preservation). $200-300 \mathrm{mg}$ of dead nauplii of Artemia salina were put on top of the suspension in each tube, and then the carcasses and mineral particles were allowed to settle together. The nauplii accumulated in the middle or in the upper part of the kaolinite sediment. In silica, the nauplii sank approximately with the same speed as the smallest particles, so the carcasses were deposited within the thin top layer of the sediment. In clinochlore and chamosite, the particles sank faster than the dead nauplii, so the majority of the nauplii were concentrated in the topmost layer and at the surface of the sediment. To cover them on top, we added a portion of the respective sediment (clinochlore or chamosite, according to the type of experiment). Montmorillonite formed a thin colloidal solution which was gradually settling down throughout the 5-year experiment. Carcasses were distributed in the middle and lower parts of the colloid; their concentration gradually increased from top to bottom. The bright orange coloration of the 
nauplii was clearly visible in all sediments. We used the same sediments without nauplii as controls; there was also a sediment-free control (nauplii in the ASW).

All tubes were sealed by one layer of Parafilm, which decreases evaporation and gas exchange but does not block these processes completely. Then the tubes stayed undisturbed in the dark at room temperature $\left(25-28^{\circ} \mathrm{C}\right)$. After 1 year (5 years for the montmorillonite) they were opened and analyzed.

There were 15 replicate tubes for the kaolinite, which were used to demonstrate the robustness of the decay pattern (Naimark et al., 2018a). There were also three replicate experiments (tubes) for the clinochlore, and two for the clinochlore control and the chamosite. Other experiments had no replication. All replications demonstrated the same decay pattern and very similar $\mathrm{pH}$ changes and degree of preservation of the carcasses (Naimark et al., 2018 a, b).

\subsection{Degree of preservation of A. salina nauplii.}

Small portions of the sediment with carcasses were put in the Petri dish, diluted with ASW, and investigated under optical microscope (Zeiss Stemi SV11) to count the nauplii and assess the degree of their preservation. We categorized the remains in five groups according to the presence of morphologically recognizable limbs and gut and the general body shape. The procedure and the characteristics of the five preservatonal groups are described in detail in Naimark et al., 2018c.

Group 1 comprised carcasses with all limbs, gut and body shape well preserved. Specimens in group 2 had well preserved limbs and body shape but no traces of the gut. Unlike freshly killed specimens or specimens from other preservational groups, the group 2 specimens were rigid and did not tend to fold in wrinkles when placed on a hard surface. Group 2 was rare in sediment-free controls but common in sediments. Groups 3-5 comprised specimens with preservation gradually deteriorating from only moderately damaged cuticle, gut and limbs in group 3 to separate limbs or limbless bodies in group 5 (Naimark et al., 2018c). The overall degree of preservation was estimated as the ratio of the well-preserved groups 1 and 2 to the poorly preserved groups 3,4 , and 5 .

\section{5. pH measurements.}

To measure $\mathrm{pH}, 0.5-1 \mathrm{~mL}$ samples were taken by a pipette from the water column 10-15 cm above the sediment, from the water-sediment interface (including 1-2 $\mathrm{mm}$ of water above the sediment and the uppermost sediment layer), and from the middle of the sediment. For the montmorillonite variant, samples were taken 5 $\mathrm{cm}$ under the water surface, $1 \mathrm{~cm}$ above the red spot (see below), in the middle of the red spot, $1 \mathrm{~cm}$ under the red spot, and $1 \mathrm{~cm}$ above the bottom of the tube.

All pH measurements were performed within 2 days after opening the tubes; during this time the samples were stored at $+4^{\circ} \mathrm{C}$. Liquid samples were tested according to the standard protocol using a combination glass $\mathrm{pH}$ electrode, calibrated in a standard buffered solution. Portions of the sediment were stirred using a vortex type stirrer without preliminary filtration until a uniform suspension was formed, and then the $\mathrm{pH}$ was measured with the same $\mathrm{pH}-$ meter 3-5 times for each sample (the results represent an average of these measurements).

\subsection{Mineralogical analyses.}

Samples for mineralogical analysis were taken from the middle of the sediments (where numerous carcasses were buried), or from the red layer (see below) in the case of montmorillonite. Sediment samples were investigated by Simultaneous Thermal Analysis (STA) that combines differential scanning calorimetry (DCA) and thermogravimetry (TG). TG/DCA curves were recorded with the STA equipment (NETZSCH STA

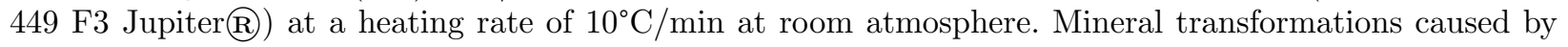
organic decay in kaolinite and clinochlore were described earlier (Naimark et al., 2018a, b). Here we report the transformations in montmorillonite and chamosite in comparison with correspondent controls without nauplii.

\subsection{Elemental composition of the exhumed nauplii.}


Fine anatomical structures and elemental composition of the carcasses were studied under SEM (Zeiss EVO50) and associated SEM/EDX (energy dispersive X-ray spectroscopy INCA Oxford 350). To prepare the samples for SEM analysis, the nauplii were rinsed of salts and sediment particles, as described in Naimark et al., 2018c. SEM imaging was performed on glass supports, and SEM/EDX point analyses on copper supports to allow for measurement of $\mathrm{Al}, \mathrm{Si}$, and $\mathrm{Fe}$. We analyzed separately the adhered mineral particles and the surface tissues of the carcasses (free of bacteria and visible adhered mineral particles). This allowed us to distinguish between the tissue intake of dissolved elements and mere adhesion of minerals.

\subsection{Molecular content of the exhumed nauplii: FT-IR spectroscopy.}

The exhumed carcasses were tested for the molecular content in a Fourier-transform infrared (FT-IR) spectrometer Vertex 70 (Bruker Optik $\mathrm{GmbH})$ with a GladiATR attenuated total reflection (ATR) attachment with a diamond crystal (Pike Technologies). The range of spectra registration was $6000-350 \mathrm{~cm}^{-1}$ with the resolution $2 \mathrm{~cm}^{-1}$, number of scans - 256. 10-15 carcasses were rinsed in distilled water and then transferred on the crystal and dried directly on it. The spectrum was registered after complete drying. Sediment particles from the experimental tubes (Artemia with kaolinite, montmorillonite, silica, clinochlore and chamosite) were also washed in distilled water and dried in the same way as the carcasses; their spectra were compared with the corresponding carcasses. We also compared the spectra of the carcasses from the sediments, from sediment-free control, and freshly killed nauplii prepared in the same way. To estimate the initial adherence of sediment particles to the nauplii, we used freshly killed nauplii incubated in kaolinite for 1 day and then rinsed and dried. To investigate the difference between well and poorly preserved carcasses, we applied differential FT-IR testing to the representatives of preservational groups 1-2 and 5 from kaolinite.

\subsection{Deposition of aluminium on Spongilla lacustris, Euglena gracilis and Dictyostelium dis- coideum studied by lumogallion staining.}

E. gracilis cells were killed by liquid nitrogen freezing, transferred to glass slides and dried briefly to adhere to the glass surface. S. lacustris were processed in small Petri dishes. The culture of $D$. discoideum with unicellular amoebae and different multicellular stages (mounds, sorogens, and fruiting bodies) was washed off from the agar plate with distilled water and transferred onto glass chamber slides. The cells and multicellular structures representing different developmental stages were killed with sodium azide and left to air dry briefly to adhere to the bottom of the glass chamber. Sodium azide was removed by rinsing with distilled water.

Treatment with aluminium was carried out by incubation with $1 \mathrm{mM}$ solution of alum $\left(\mathrm{KAl}\left(\mathrm{SO}_{4}\right)_{2}\right)$ in distilled water at room temperature for $30 \mathrm{~min}$. The alum solution was removed, the specimens on the glass slides or in Petri dishes were rinsed 5 times with distilled water to remove unbound aluminium, fixed in $2 \%$ paraformaldehyde (PFA) for $20 \mathrm{~min}$, and rinsed 2 times with distilled water to remove PFA.

The presence of bound aluminium was detected with standard lumogallion (5-chloro-3[(2,4dihydroxyphenyl)azo]-2-hydroxybenzenesulfonic acid) staining, described elsewhere and used to detect aluminium at low (around $2 \mu \mathrm{M}$ ) concentrations (Kataoka et al., 1997; Mold et al., 2014). The samples were stained in $0.025 \mathrm{mM}$ lumogallion in $0.1 \mathrm{M}$ sodium acetate buffer $\mathrm{pH} 5.2$ at $50{ }^{\circ} \mathrm{C}$ for 50 min in the dark. The lumogallion solution was removed, and the stained preparations were rinsed with distilled water. In the case of $D$. discoideum, samples were also counterstained with the DNA dye Hoechst 342 in a conventional manner to visualize the positions of cell nuclei. Prepared samples covered with a cover-glass were immediately examined under a Leica DMR Fluorescent Microscope with an UV excitation and emission at $488 \mathrm{~nm}$ (green, characteristic for lumogallion-Al complex); colonial amoebae were also examined at $408 \mathrm{~nm}$ (blue, Hoechst-DNA). E. gracilis preparations were also examined under the confocal fluorescent microscope Leica TCS SP5 at UV excitation and $488 \mathrm{~nm}$ emission to reveal cellular localization of the fluorescent structures. Each sample was prepared in triplicate.

In the cell autofluorescence controls, both incubation in alum and lumogallion staining steps were omitted. The lumogallion non-specific binding controls ("Al-negative") lacked the alum incubation step.

\section{RESULTS}




\subsection{The pattern of decay of the model soft-bodied organismArtemia salina in different sedi- ments.}

In our burial experiments, we used five different model sediments with various mineral and chemical compositions: chamosite, clinochlore, kaolinite, montmorillonite, and artificial silica (Table 2, see Materials and Methods). The experimental aqueous sediments with the buried nauplii of $A$. salina (see Methods) quickly (within the first week) changed their coloration (Figure 1). In the kaolinite, clinochlore, and chamosite, prominent light-colored spots formed around every carcass (Figure $1 \mathrm{C}, \mathrm{F}, \mathrm{I}$ ). In the silica, dead nauplii clustered in a subsurface layer which remained light-colored on the otherwise darkened background (Figure $1 \mathrm{~K}, \mathrm{~L}$ ). In the montmorillonite, a bright red layer formed by the 5 th month and stayed well visible to the end of the experiment ( 5 years, Figure $1 \mathrm{M}$ ). The patterns in the sediment controls (prepared by the same protocol but without any buriedArtemia ) differed dramatically: their coloration remained unchanged (Fig 1 A, D, G, J). This difference implies some active chemical, organic-mineral processes within the sediments that contain decaying soft-bodied organisms.

\subsection{The degree of preservation of the model SBO in different sediments.}

In order to quantitatively assess the degree of preservation of the buried nauplii, we assigned them to five preservational groups which reflect successive stages of decomposition: From the perfect preservation of the body shape, the limbs, and sometimes also the gut (preservational groups 1 and 2) to partial (groups 3,4) or complete (group 5) decay of the limbs and the gut (see Materials and Methods for details).

The best preserved carcasses (group 1) from the montmorillonite, kaolinite, and silica retained very fine external anatomical structures such as the filter apparatus on antennae 2 and the chaetae (Figure 2 F, G). They also preserved the naturally shaped remains of the gut (Figure $2 \mathrm{~A}$, E, Figure $3 \mathrm{~A}$ ), which usually rapidly dissolves when buried in liquid media without sediment (Butler et al., 2015). We never observed such fine anatomical details in the representatives of groups 3,4 and 5 .

Group 2 was comprised of well-shaped rigid external integument with finely preserved limbs but completely decayed internal anatomy (Figure $2 \mathrm{D}$ ). This group is specific to decay in sediment as it was abundant in all sediments but almost absent in the sediment-free control (Table 3; Butler et al., 2015; Naimark et al., 2018b).

The montmorillonite experiment continued for 5 years, and we expected the majority of the remains to be in groups 4 and 5 . Contrary to our expectations, the carcasses from this five-year-old sediment were the best preserved (Figure $2 \mathrm{~A}, 3 \mathrm{~A}$ ), with the majority of the remains belonging to groups 1 and 2 .

To quantitatively compare the preservation of the nauplii in each sediment, we used the ratio of the number of well-preserved specimens (groups 1 and 2) to the number of poorly preserved ones (groups 3, 4, and 5) (Table 3). This ratio (we called it "degree of preservation") varied widely across the sediments, being the highest in the montmorillonite and kaolinite and the lowest in the clinochlore. However, the score for the clinochlore was still higher than for the sediment-free control (Table 3).

The results imply that the preservation potential of SBO improves considerably when the carcass is buried in sediment, and that different sediments may provide different opportunities for preservation. In order to elucidate the main factors controlling the preservation, we analyzed changes in $\mathrm{pH}$ and mineral composition of the sediments and in the elemental and chemical composition of the carcasses.

\subsection{Decay-induced changes of $\mathrm{pH}$.}

The analysis revealed a complex pattern of $\mathrm{pH}$ gradients in the experimental tubes. Inside the sediments with the buried carcasses, the $\mathrm{pH}$ varied from acidic $(\mathrm{pH} 6.05$ in the kaolinite) to alkaline ( $\mathrm{pH} 11$ in the montmorillonite) (Table 4). This is very different from the original (control) values of the artificial sea water $(\mathrm{pH}$ 7.8) which was used in experiments with the kaolinite, silica, clinochlore and chamosite, and fresh water $(\mathrm{pH}$ 7.0) used in the montmorillonite experiment. The $\mathrm{pH}$ of the liquid above the sediment with nauplii became more alkaline than inside the sediments (except montmorillonite). The difference between the $\mathrm{pH}$ in 
the middle of the sediment and the supernatant was more pronounced in the experimental tubes with nauplii than in the controls without nauplii (Table 4). Besides, in three experimental sediments (kaolinite, silica and clinochlore), the $\mathrm{pH}$ had a local maximum in the water-sediment interface (Table 4, shown in bold). This means that the $\mathrm{pH}$ in the topmost layer of the sediment was higher than in the middle of the sediment and in the water column above the sediment (silica, clinochlore), or, in the case of the kaolinite, there was a thin layer of water immediately above the sediment where the $\mathrm{pH}$ was lower (7.04) than in the topmost sediment (7.13), although elsewhere in the water column the $\mathrm{pH}$ was high (7.76; Table 4).

This complex pattern of $\mathrm{pH}$ gradients becomes even more intricate when we consider the light-colored spots around the carcasses. These spots probably imply lower local $\mathrm{pH}$ because the discoloration of the otherwise evenly darkened kaolinite or dark-green clinochlore can be explained by the acidic dissolution of dark-colored compounds (e.g., hydrotroilite in the kaolinite sediment (Naimark et al., 2016a). We could not directly measure the $\mathrm{pH}$ within the spots but microenvironmental $\mathrm{pH}$ minima have been shown to form locally around decaying biomass in marine sediments (Zhu et al., 2006).

The results are compatible with the idea that decaying organic matter induces chemical changes in the surrounding medium that potentially can affect the sediment and the set of ions released by sediment particles (see below).

\subsection{Biochemical composition of the carcasses: Spectral characterization.}

There are two main hypotheses that consider the biochemical components of the soft body as the key factor of preservation. The first one is focused on the presence of recalcitrant tissues such as chitin (Butler et al., 2015), while the second one emphasizes the stability of proteins tanned by aluminium ions (Wilson, Butterfield, 2014; Naimark et al., 2016a). To evaluate the importance of the two mechanisms, we assessed the sustainability of chitin and proteins in the carcasses with contrasting degrees of preservation (Figure 3 A, B) using FT-IR spectroscopy (see Materials and Methods) (Figure 3 C-H).

In all carcasses (except for the sediment-free control), the FT-IR profiles consisted of two parts: the bands corresponding to chemical bonds in organic molecules, and the bands that correspond to the mineral (inorganic) components of the sediment. We first considered the organic part (Figure $3 \mathrm{C}-\mathrm{E}$ ).

The spectra of all the studied A. salina samples from the different sediments were similar. The spectral pictures of the excellently preserved montmorillonite-hosted specimens and poorly preserved clinochlorehosted samples showed little to no difference (Figure $3 \mathrm{D}, \mathrm{E}$ ). In the carcasses from different clays with different degree of preservation, the same peaks were present, and the differences affected only the intensities of the peaks. Moreover, the best and worst preserved specimens belonging to groups 1 and 4-5 from the kaolinite also had very similar FT-IR spectra (Figure 4). The spectra also did not differ much from the two controls: live nauplii and the decayed sediment-free control (Figure $3 \mathrm{C}$ ). The protein characteristic bands (known as Amid I and II between 1600 and $1700 \mathrm{~cm}^{-1}$ and 1510 and $1580 \mathrm{~cm}^{-1}$ respectively; Figure $3 \mathrm{E})$ varied little across the carcasses from different sediments. The same is true for the chitin characteristic bands (between 3400 and $3500 \mathrm{~cm}^{-1}$ and 2950-2800 $\mathrm{cm}^{-1}$ (Negrea et al., 2015)) (Figure 3D).

The second, inorganic part of the spectra occupies intervals at wavelength $<1300 \mathrm{~cm}^{-1}$. In all exhumed carcasses, these profiles repeated the spectra for the corresponding sediments (Figure 3F, G). In the SEM images, we could see small (less than $1 \mu \mathrm{m}$ ) sediment particles that stayed attached to the organic surface (Figure $2 \mathrm{G}$ ) even after multiple intensive rinsings. So, can the similarity of the spectra of carcasses and sediments be explained by mere adherence of inorganic particles to the carcasses? Probably not, because the 1-day control specimens, which had been kept in the kaolinite sediment for one day after death and then rinsed according to the common protocol, showed a much less pronounced signature of kaolinite (Figure 3 $\mathrm{H})$. This means that mineral particles did not adhere to a nauplial carcass immediately after deposition, but it took some time for the minerals to form strong mineral-organic bonds or to become incorporated into organic tissues.

Overall, the results presented in this section do not demonstrate any simple relationship between the rate of 
decomposition of chitin and/or proteins and the degree of preservation of the carcasses.

\subsection{Elemental composition of the carcasses.}

In this analysis, we aimed to identify inorganic ions that enhance the preservation of SBO. Thus we focused on the correlation between the deposition of different elements on the carcasses and the degree of their preservation. We used SEM/EDX multiple point analysis to measure chemical elements (1) in the patches of tissues free of visible sediment particles and bacteria and (2) in the sediment particles that were adhered to tissues (Figure 5, Table 5).

In the three sediments with the highest degree of preservation (montmorillonite, kaolinite and silica, Table 3 ) the carcasses were enriched in aluminium and silicon. In the chamosite and clinochlore, where the preservation was poor, aluminium and silicon entered the tissues in minimal amounts (Table 5). Iron appeared in increased amounts in the well preserved carcasses from the montmorillonite and in the poorly preserved carcasses from the chamosite. The chamosite-hosted carcasses contained much more iron and less magnesium than the carcasses from the clinochlore, in concordance with the initial chemical composition of the two sediments (Tables 2 and 5, Figure $6 \mathrm{~A}$ ).

Calcium was detected in the carcasses from all sediments and ASW, regardless of the initial elemental composition of the sediments and water. The results imply that calcium was effectively absorbed by the carcasses both from the sediment and from the water (Figure $6 \mathrm{~B}$ ). Other elements from the dissolved sediments $(\mathrm{Al}, \mathrm{Si}, \mathrm{Mg}, \mathrm{Fe})$ apparently have entered the carcasses in a more passive way, and this is why the greater the amount of an element in the sediment, the higher is its content in the body tissues (Figure 6 B).

Different elements appeared in the solutions due to leaching of the corresponding sediments. This is in concordance with mineralogical transformations detected in the experimental sediments. The results of mineralogical analysis (STA, see Material and Methods) of the kaolinite and clinochlore were reported previously (Naimark et al., $2018 \mathrm{a}, \mathrm{b}$ ). The results for the chamosite and montmorillonite are shown in Figure 7. They show that decaying organic matter promotes structural disintegration of the sediment and leaching of ions. In the montmorillonite, the strong alkaline environment accelerated the release of silicon species to a greater extent than in the artificial silica sediment with moderate alkalinity (Crundwell, 2014).

\subsection{Accumulation of iron.}

The accumulation of iron in the buried carcasses needs additional clarification. SBO fossils are often pyritized to a varying extent, and the deposition of iron has been considered among the main mechanisms for SBO preservation (e.g., Schiffbauer et al., 2014). Two of our experimental sediments, chamosite and montmorillonite, showed interesting signatures of iron accumulation associated with the carcasses. Some exhumed carcasses from these sediments were scattered with small spherules either attached to the organic surface or located inside the thin integuments (Figure 8). These spherules varied widely in size, which is common for mineral particles but unusual for bacterial pseudomorphs (Schopf, 1976). According to the SEM/EDX point analyses (Figure $8 \mathrm{C}, \mathrm{F}$ ) the spherules contained Fe and $\mathrm{S}$ in an atomic ratio of approximately 1:3, which is consistent with ongoing pyritization (Rickard, Luther, 2007).

Mineralogical STA analysis confirmed that, in the presence of the buried nauplii, the montmorillonite disintegrated almost completely within 5 years (Figure $7 \mathrm{~A}$ ). The iron ions diffused from the mineral sediment upward along the $\mathrm{pH}$ and oxygen gradients and accumulated in the interfacial layer between the oxygendepleted and oxygenated phases. When concentrated in this layer, $\mathrm{Fe}^{2+}$ transformed to $\mathrm{Fe}^{3+}$ in a form of ferrihydrite, turning the coloration of this layer to brightly red (Figure $1 \mathrm{M}$ ) and inducing a decrease of $\mathrm{pH}$ from 10.9-11.0 to 9.63-9.70 (Table 4). Ferrihydrite became stabilized by silicate ions that were released into the media due to the alkaline dissolution of montmorillonite (Rozalén et al., 2008).

Importantly, organic tissues served as a template for the nucleation of the released iron compounds. We failed to find such iron-rich spheres in the loose sediment around the carcasses.

In the chamosite, where the initial iron content was high (Table 2) and iron subsequently leached from the 
mineral in the presence of the buried nauplii (Figure $7 \mathrm{~B}$ ), all iron-rich spherules were also adhered to organic tissues (Figure 8). The results imply that such pyritization, even if it occurs rapidly, does not necessarily provide good preservation, because in our chamosite-based system the preservation of $A$. salina was generally poor.

\subsection{Deposition of aluminium on the surface of unicellular and multicellular organisms.}

The results reported in the previous sections suggest that, in our experimental context, aluminium and silicon affected the preservation of SBO, probably by rapid binding with certain biomolecules. In order to successfully resist decay, an organic tissue presumably should adsorb aluminium or silicon ions before it becomes considerably degraded. To do so, it must contain molecules that effectively bind aluminium or silicon. The best candidates for such biomolecules are cell adhesion molecules and related extracellular molecules (CAMs and ECMs), because they evolved to provide effective adhesion to different charged substrates. Such molecules are typically absent in most unicellular organisms. Thus, we hypothesized that dead multicellular organisms should deposit aluminium and silicon more efficiently than unicellular organisms. To test this hypothesis, we investigated the deposition of aluminium on the carcasses of some unicellular and multicellular organisms.

In this experiment, we used three model organisms: freshwater unicellular flagellate Euglena gracilis, freshwater spongeSpongilla lacustris (a primitive multicellular organism), and soil social amoeba Dictyostelium discoideum. While the two former organisms are different in all biochemical aspects, $D$. discoideumhas both unicellular and multicellular stages. Under certain environmental conditions unicellular amoebae gather to form a loose multicellular aggregate. This then transforms into a tight aggregate (mound), then into a motile "slug", a culminant, and finally a well-differentiated spore-producing fruiting body. Thus, in $D$. discoideum , we have a convenient example of unicellular and multicellular organisms with essentially the same biochemistry except for a set of CAMs and ECMs which is expressed predominantly at multicellular stages (these molecules are essential for cell-to-cell adhesion).

After the incubation of the dead model organisms with the $\mathrm{Al}^{3+}$-containing solution and removal of unbound aluminium, cell-bound $\mathrm{Al}^{3+}$ was detected by fluorescent staining with lumogallion, a very sensitive dye for bound aluminium detection. Lumogallion-Al complex has strong fluorescence at $488 \mathrm{~nm}$ (green); thus, the intensity of green fluorescence allows for the comparison of the amount of bound aluminium between the samples.

The sponge showed a very clear response to incubation with $\mathrm{Al}^{3+}$ and subsequent lumogallion staining. Autofluorescence in the non-stained control was negligible, as well as the fluorescence in the lumogallion-stained Al-negative control. However, Al-incubated lumogallion-stained specimens emitted bright green fluorescence (Figure 9 A-C).

The cells of E. gracilis had moderate autofluorescense and relatively intense fluorescence in the Al-negative control. The incubation with aluminium did not add any intensiveness to the emission as observed under the confocal microscope (Figure 9 D-F). The confocal microscopy also allowed us to recognize that autofluorescence and emission in the Al-negative control was mostly localized in some intracellular structures (probably chloroplasts and vacuoles), but not on or near the cell surface (Figure 9 G-I). Importantly, in the cells incubated with $\mathrm{Al}^{3+}$, fluorescence of the outer pellicle was not more intense than in the Al-negative cells (in fact, both fluorescent signals were equally low). The results imply that aluminium did not accumulate on the dead cells of E. gracilis in the same fast and efficient way as on the cells of the sponge.

The cells of $D$. discoideum at multicellular stages (culminants and fruiting bodies) emitted brightly at $488 \mathrm{~nm}$ (Figure $9 \mathrm{O}, \mathrm{P}$ ). The strong Al-lumogallion signal from the multicellular structures was clearly different from the weak autofluorescence signal of the fruiting body (Figure $9 \mathrm{~K}$ ) and the weak emission of the Al-negative control (Figure $9 \mathrm{M}$ ). Single amoebae showed very low fluorescence in all cases (Figure $9 \mathrm{~J}, \mathrm{~L}, \mathrm{~N}$ ).

The results imply that the multicellular stages of $D$. discoideumexpress some aluminium-binding molecules which are present on the cell surface and retain their affinity to aluminium after cell death; these molecules 
are absent at the unicellular stage. In the case of social amoebae, the most plausible candidates are indeed cell adhesion molecules and related extracellular molecules (CAMs and ECMs). Unicellular stages (single amoebae) do not express CAMs, while the progression of $D$. discoideum through its multicellular stages is accompanied by the expression of several cell surface CAMs (Coates, Harwood, 2001; Siu et al., 2011). Sponges are multicellular animals that possess a large set of CAMs and ECMs, while Euglenozoa lack them (Seymour et al., 2004; Fahey, Degnan, 2010).

\section{DISCUSSION}

\subsection{Decay-induced chemical processes in the sediment.}

Decay in the sediment produces a range of chemical reactions that can enhance the preservation potential of SBO. A necessary prerequisite for many of them to start is the fine-grained texture of the sediment that slows the diffusion of oxygen and dissolved ions (Allison, 1988). Clay particles are usually of fine and ultrafine size, and therefore clays are expected to enhance the preservation potential of a buried carcass. Other sediments such as fine-grain silica in our experiments can also trigger reactions necessary for preservation.

The arrested diffusion results in increasing concentrations of different ions around the decaying body. Chemical gradients thus established can form a spot-like or layer-like morphology in the sediment (Figure 1). Although this chemical heterogeneity has been often overlooked in the discussion of SBO preservation, it invokes at least two conditions that can favor preservation. The first one is the fast accumulation of mineralizing agents (e.g., ions of $\mathrm{Ca}, \mathrm{Mg}, \mathrm{Al}, \mathrm{Si}, \mathrm{Fe}, \mathrm{P}$ ) released via acidic or alkaline hydrolysis of the sediment. The second one is the peak of the $\mathrm{pH}$ at the water/sediment interface (Table 4). Similar peaks can be found in the topmost layers of some modern organic-rich marine sediments (Zhu et al., 2006). If there is no bioturbation, this peak of the $\mathrm{pH}$ can sometimes induce the formation of calcium-rich sealing cement at the water/sediment interface (Naimark et al., 2016a). Surface cementation of this kind is a widely recognized phenomenon in SBO fossil localities, although its origin is poorly understood (Gaines et al., 2012). Our results suggest that it may result from the increased $\mathrm{pH}$ in the top layer of organic-rich sediment.

The repertoire of mineralizing ions depends on the type of sediment. Its chemical and physical properties determine how the $\mathrm{pH}$ will change in response to organic decay, and which elements will leach. We found a good concordance between the transformation of the sediments and the composition of cations permeating the carcasses. Therefore, the diversity of primary host sediments is expected to produce a diversity of the resulting elemental content of SBO fossils.

Five experimental sediments led to quite different degrees of preservation of the model soft-bodied organism (Table 3). It does not necessarily mean that the same sediments would provide the same degrees of preservation in natural environments. Their potential to preserve soft carcasses depends on other factors as well. The montmorillonite experiment is revealing in this sense. It is known that soft bodied fossils are rare in rocks containing montmorillonite or its hydrated product illite (Anderson et al., 2018), apparently because montmorillonite is comparatively stable in the common burial conditions. In our experimental conditions, however, the $\mathrm{pH}$ in the montmorillonite sediment became alkaline (Table 4), thus triggering the dissolution of the montmorillonite and mineralization and preservation of the buried soft-bodied organisms.

More research is needed to elucidate the particular factors mediating the decay and preservation of SBO in different sediments. However, our results imply that different fine-grained sediments (such as the clays and the artificial silica we used) can, under some conditions, facilitate the formation of specific microenvironments and chemical gradients in the vicinity of the buried carcassess that can affect their preservation potential in a variety of ways.

\subsection{Deposition of aluminium and silicon is an important mechanism of preservation of the} soft-bodied organisms.

The ions released from the mineral matrices exhibit different preservation ability. Aluminium and silicon ions (released in the form of amphoteric oxides) provided the best preservation of the organic structures (Figure 
6). We acknowledge that some other elements, which were absent or rare in our experimental context, may also enhance preservation (e.g., phosphorus).

Magnesium, iron and calcium were readily deposited on the organic tissues, but their abundance in the carcasses was not associated with better preservation. Nevertheless, owing to their fast deposition on the carcasses, they probably can create 2D-organo-mineral "portraits" in the sediment that are visually accentuated by the high concentration of the corresponding element (especially iron). In the presence of aluminium and/or silicon that slow down decay, carbonaceous films veneered by iron, calcium or magnesium may be formed on the surface of the carcasses. In the case of iron-rich sediments, a pyritized veneer can penetrate inside the tissues to produce a more or less pyritized fossil (Schiffbauer et al., 2014). It needs to be emphasized that the fast deposition of an element on the carcass and its subsequent accumulation in decaying tissues does not nesessarily mean that this element enhances preservation. We need to distinguish the two processes: the fast deposition of elements and their action as preservatives. This is especially important in the context of the current debates about the role of iron in preservational pathways (Schiffbauer et al., 2014; Newman et al., 2019).

In all experiments reported here, including the sediment-free control, calcium ions entered the body tissues very effectively (Figure 6, Table 5). Thus, calcification is expected to occur more frequently than other preservation pathways in aluminium- and silicon-containing sediments. However, without aluminium and silicon (or other putative preservation-enhancing ions), calcium does not appear to ensure good preservation. Interestingly, even highly calcified SBO fossils were found coated with a thin layer of aluminosilicate, e.g., in the Silurian Herefordshire Lagerstätte (Siveter et al., 2020).

In our experiments, good preservation was associated with strong adherence of sediment particles to decaying bodies; some specimens were wrapped in clay "envelopes" (Figure 2). As a result, surface body tissues became more rigid and the body retained its shape (the characteristic feature of the preservational groups 1 and 2).

Importantly, the chemical pathways of SBO preservation discussed here do not require any unusual environmental conditions and occur relatively quickly. Preservational processes take place whenever a sufficient amount of dead organic bodies is buried under a layer of fine-grained sediment. According to the mineral composition of the sediment and probably some other characteristics of the system, buried carcasses may become minerlized and fossilized in different modes and by different compounds. Aluminium and silicon are possibly required for SBO preservation, but they are among the most abundant elements in sedimentary rocks. Owing to diverse and ubiquitous contexts for SBO preservation, Konservat-Lagerstätten localities are expected to be quite numerous. The recent data seem to confirm that SBO fossil localities are not taphonomic rarities: during the last two decades, ten times more Lagerstätten have been described than during more than 100 years since their discovery in the $19^{\text {th }}$ century: from 53 Lagerstätten occurrences in 1997 to 670 in 2017 (Muscente et al., 2017).

\subsection{Cell adhesion molecules probably play a role in preservation of the soft-bodied organisms.}

Despite the popular idea that durable integuments (e.g., chitinous cuticles) are essential for fossil preservation, in some Lagerstätten fossil animals with and without such durable tissues are found in comparable numbers (Fu et al., 2019).

The results of our FT-IR analysis (Figure 3) show that differently preserved specimens have similar spectral portraits, implying that different biochemical components probably had similar rates of decay. More specifically, we found that the best preserved specimens were not those that retained more chitin or proteins. Although we were not able to measure these components precisely, the similarity of the spectra probably indicates that SBO with different bulk biochemistry may have comparable chances of fossilization, and that durable chitinious integuments may play only a secondary role in the preservation of SBO.

Given that Konservat-Lagerstätten are diverse and numerous, and that durable tissues are not an imperative for SBO preservation, then some other biochemical factors may be expected to play the key role in different preservation pathways. The idea of key biochemical factors seems plausible because the mineralization of 
a dead organism probably should begin with binding of mineral ions to some cell surface molecules. The obvious candidates are acidic and very acidic proteins, glycoproteins and polysaccharides which have been shown to facilitate nucleation of mineral crystals during skeletal biomineralization in eukaryotes (Marin, Luquet, 2007). We hypothesize that there is a special group of these acidic biomolecules that play a crucial role in the fossilization of SBO: cell adhesion molecules and related extracellular matrix molecules (CAMs and ECMs) that evolved in multicellular animals (and some other organisms like social amoebae) to ensure cell-cell and cell-substrate adhesion.

CAMs and ECMs have the ability to adhere to mineral particles and bind ions; many types of CAMs are known to bind inorganic ions as part of their physiological function (Brown et al., 2018; Sotomayor, Schluten, 2008). From this perspective, the fossilization of dead multicellular soft-bodied organisms via fast binding of certain inorganic ions (e.g., aluminium and silicon ions) would be an inevitable consequence of a certain stage of evolution of multicellularity, when a set of CAMs and ECMs became sufficiently developed. If our hypothesis is correct, then the crown groups of metazoans with fully developed sets of CAMs and ECMs would have a higher chance of leaving a trace in the fossil record compared to basal groups with less advanced or numerous CAMs and ECMs. For example, sets of adhesive molecules are poor or lacking in basal holozoans (including choanoflagellates), which, in the absence of a mineral skeleton, makes their fossilization very unlikely.

The hypothesis explains several enigmatic features of the fossil record: the extreme scarcity of the record of basal Metazoa who probably had only a few primitive CAMs and ECMs; the poor record of non-skeletal holozoans which, according to phylogenetic reconstructions, should have been present since the Proterozoic and throughout the Phanerozoic (Sharpe et al., 2015; Dohrmann, Wörheide, 2017; Betts et al., 2018). The rich fossil record of bacterial mats can be explained by their sheaths of acidic polysaccharides and mucins (one class of CAMs). Speculating on the role of CAMs and ECMs in preservation, we need to take into account that cell surface biochemistry and extracellular structures in plants and fungi differ from those in animals. Thus, their preservation is probably governed by other molecular mechanisms and should be addressed separately.

A critical review of the evolution of CAMs and ECMs and its comparison with the trends in the fossil record of Metazoa may bring interesting insights into the chronology of the early evolution of animals. The fast evolution and diversification of CAMs and ECMs probably can, to some extent, account for the explosive emergence of diverse multicellular organisms in the Cambrian fossil record.

\section{ACKNOWLEDGEMENTS}

We are grateful to J. Rudenskaya from the Faculty of Biology, Moscow State University who provided us with the culture of Euglena gracilis, and to I. Aldobaeva for culturing Dictyostelium. The study was supported by the Russian Science Foundation: FT-IR measurements, grant 19-13-0011; staining and confocal microscopy, grant 18-29-13014. This research was done using equipment of the Core Centrum of the Institute of Developmental Biology, Russian Academy of Sciences.

\section{CONFLICT OF INTEREST}

The authors declare that they have no competing interests.

\section{AUTHOR CONTRIBUTION}

EN: Conceptualization (lead), investigation (lead), methodology (equal), supervision (lead), formal analysis (lead), visualization (lead), writing - original draft (lead), writing - review \& editing (equal). DK: Conceptualization (equal), methodology (equal), formal analysis (supporting), writing - original draft (equal), writing - review \& editing (equal). NB: Investigation (equal), methodology (supporting), formal analysis (equal), writing - original draft (supporting), writing - review \& editing (supporting). VG: Investigation (equal), methodology (supporting), writing - original draft (supporting), writing - review \& editing (supporting). MK: Conceptualization (equal), formal analysis (equal), writing - original draft (equal), writing review \& editing (supporting). YL: Investigation (equal), formal analysis (equal), methodology (equal). AM: 
Conceptualization (equal), formal analysis (equal), writing - original draft (equal), writing - review \& editing (equal). MN: Investigation (supporting), methodology (equal), formal analysis (supporting), writing original draft (supporting), writing - review \& editing (supporting). AS: Investigation (equal), methodology (supporting), formal analysis (equal), writing - original draft (supporting), writing - review \& editing (supporting). DV: Investigation (equal), methodology (supporting), formal analysis (equal), writing - original draft (supporting), writing - review \& editing (supporting).

\section{DATA ACCESSIBILITY}

Data supporting the results in the paper are available at Open Science Framework (elemental composition of the exhumed carcasses and sediment particles: https://osf.io/w5gxj/, $\mathrm{pH}$ in the different layers of experimental sediments: https://osf.io/2jzfg/).

\section{REFERENCES}

Allison, P.A. (1988). The role of anoxia in the decay and mineralization of proteinaceous macro-fossils. Paleobiol . 14, 139-154.

Anderson, R.P., Tosca, N.J., Gaines, R.R., Koch, N.M., \& Briggs, D.E.G. (2018). A mineralogical signature for Burgess Shale-type fossilization. Geol . 46, 347-350.

Berner, R.A. (1968). Calcium carbonate concretions formed by the decomposition of organic matter. Science . $159,195-197$.

Betts, H.C., Puttick, M.N., Clark, J.W., Williams, T.A., Donoghue, P.C.J., \& Pisani, D. (2018). Integrated genomic and fossil evidence illuminates life's early evolution and eukaryote origin. Nature Ecology $\&$ Evolution . 2, 1556-1562.

Briggs, D.E.G., \& Kear, A.J. (1997). Decay and preservation of polychaetes: Taphonomic thresholds in soft-bodied organisms. Paleobiol . 19 , 107-135.

Brown, K.L., Banerjee, S., Feigley, A., Abe, H., Blackwell, T.S. et al. (2018). Salt-bridge modulates differential calcium-mediated ligand binding to integrin $\alpha 1-$ and $\alpha 2$-I domains. Sci. Rep. 8, 2916.

Butler, A.D., Cunningham, J.A., Budd, G.E.P., \& Donoghue, C.J. (2015). Experimental taphonomy of Artemia reveals the role of endogenous microbes in mediating decay and fossilization. Proc. Royal Soc. Seria B: Biol. Sci . 282, 20150476.

Butterfield, N.J. (1995). Secular distribution of Burgess Shale-type reservation. Lethaia . 28 , 1-13.

Butterfield, N.J. (2003). Exceptional fossil preservation and the Cambrian explosion. Integr. Compar. Bio l. $43,166-177$.

Coates, J.C., \& Harwood, A.D. (2001). Cell-cell adhesion and signal transduction during Dictyostelium development. J. Cell Sci . 114, 4349-4358.

Crundwell, F. K. (2014). The mechanism of dissolution of minerals in acidic and alkaline solutions: Part II, Application of a new theory to silicates, aluminosilicates and quartz. Hydrometallurgy .149 , 265-275.

Darroch, S.A.F., Laflamme, M., Schiffbauer, J. D., \& Briggs, D.E.G. (2012). Experimental formation of a microbial death mask.Palaios . $27,293-303$.

Dohrmann, M., \& Wörheide, G. (2017). Dating early animal evolution using phylogenomic data. Sci. Rep. 7, 3599 .

Fahey, B., \& Degnan, B.M. (2010). Origin of animal epithelia: insights from the sponge genome. Evol. Develop. 12, 601-617.

Földvári, M., 2011. Handbook of thermogravimetric system of minerals and its use in geological practice. Geological Inst. of Hungary (Budapest). 
Fu, D., Tong, G., Dai, T., Liu, W., Yang, Y. et al. (2019). The Qingjiang biota - A Burgess Shale-type fossil Lagerstätte from the early Cambrian of South China. Science . 363 , 1338-1342.

Gaines, R.R., Hammarlund, E.U., Hou, X., Qi, C., Gabbott, S.E. et al. (2012). Mechanism for Burgess Shale-type preservation. PNAS .109, 5180-5184.

Garson, D.E., Gaines, R.R., Droser, M.L., Liddell, W.D., \& Sappenfield, A. (2011). Dynamic palaeoredox and exceptional preservation in the Cambrian Spence Shale of Utah. Lethaia . 45 , 164-177.

Gehling, J.G. (1999). Microbial mats in terminal Proterozoic siliciclastics: Ediacaran death masks. Palaios . $14,40-57$.

Hammarlund, E., Canfield, D.E., Bengtson, S., Leth, P.M., Schillinger, B., \& Calzada, E. (2011). The influence of sulfate concentration on soft-tissue decay and preservation. Palaeontologr. Canad .31 , 141-156.

Kataoka, T., Mori, M., Nakanishi, T.M., Matsumoto, S., \& Uchiumi, A. (1997). Highly sensitive analytical method for aluminium movement in soybean root through lumogallion staining. J. Plant Res. and Environment . $110,305-309$.

Kompantseva, E.I., Naimark, E.B., Komova, A.V., \& Nikitina, N.S. (2011). Interaction of the haloalkaliphilic purple bacteriaRhodovulum steppense with aluminosilicate minerals. Microbiol . 80 , 650-656.

Marin, F., \& Luquet, G. (2007). Unusually acidic proteins in biomineralization. In Handbook of Biomineralization. Biological aspects and structure formation (ed. Bäuerlein, E.) 273-290 (Weinheim: Wiley VCH).

Martin, D., Briggs, D.E.G., \& Parkes, R.J. (2004). Experimental attachment of sediment particles to invertebrate eggs and the preservation of soft-bodied fossils. J. Geol. Soc. 161, 735-738.

McCoy, V.E., Young, R.T., \& Briggs, D.E.G. (2015a). Factors controlling exceptional preservation in concretions. Palaios . 30, 272-280.

McCoy, V. E., Young, R.T., \& Briggs, D.E.G. (2015b). Sediment permeability and the preservation of softtissues in concretions: an experimental study. Palaios . 30 , 608-612.

McMahon, S., Anderson, R.P., Saupe, E.E., \& Briggs, D.E.G. (2016). Experimental evidence that clay inhibits bacterial decomposers: Implications for preservation of organic fossils. Geol .44, 867-870.

Mold, M., Eriksson, H., Siesjö, P., Darabi, A., Shardlow, E., \& Exley, C. (2014). Unequivocal identification of intracellular aluminium adjuvant in a monocytic THP-1 cell line. Sci. Rep . 4, 6287.

Muscente, A.D., Schiffbauer, J.D., Broce, J., Laflamme, M., O’Donnell, K. et al. (2017). Exceptionally preserved fossil assemblages through geologic time and space. Gondwana Research . 48 , 164-188.

Naimark, E.B., Kalinina, M.A., Shokurov, A.V., Markov, A.V., \& Boeva, N.M. (2016a). Decaying of Artemia salina in clay colloids: 14-month experimental formation of subfossils. J. Palaeontol .90 , 472-484.

Naimark, E., Kalinina, M., Shokurov, A., Boeva, N., Markov, A., \& Zaytseva, L. (2016b). Decaying in different clays: implications for soft-tissue preservation. Palaeontol . 59, 583-595.

Naimark, E.B., Boeva, N.M., Kalinina, M.A., \& Zaytseva, L.V. (2018a). Complementary transformations of buried organic residues and the ambient sediment: results of long-term taphonomic experiments. Paleontol. J . 52, 109-122.

Naimark, E., Kalinina, M., Shokurov, A., Markov, A., Zaytseva, L., \& Boeva, N. (2018b). Mineral composition of host sediments influences the fossilization of soft tissues. Canad. J. of Earth Sci.55 , 1271-1283.

Naimark, E., Kalinina, M., \& Boeva, N. (2018c). Persistence of external anatomy of small crustaceans in a long term taphonomic experiment.Palaios . 33 , 154-163.

Negrea, P., Caunii, A., Sarac, I., \& Butnariu, M. (2015). The study of infrared spectrum of chitin and chitosan extract as potential sources of biomass. Digest J. Nanomater. and Biostructures . 10, 1129-1138. 
Newman, S.A., Daye, M., Fakra, S.C., Marcus, M.A., Pajusalu, M. et al. (2019). Experimental preservation of muscle tissue in quartz sand and kaolinite. Palaios. 34, 437-451.

Petrovich, R. (2001). Mechanisms of fossilization of the soft-bodied and lightly armored faunas of the Burgess Shale and of some other classical localities. Amer. J. Sci . 301, 683-726.

Pratt, B.R., \& Kimmig, J. (2019). Extensive bioturbation in a middle Cambrian Burgess Shale-type fossil Lagerstätte in northwestern Canada. Geol . 47, 231-234.

Raff, E.C., Schollaert, K.L., Nelson, D.E., Donoghue, P.C.J., Thomas, C.-W. et al. (2008). Embryo fossilization is a biological process mediated by microbial biofilms. PNAS . 105, 19360-19365.

Raff, E.C., Andrews, M.E., Turner, F.R., Toh, E., Nelson, D.E., \& Raff, R.A. (2013). Contingent interactions among biofilm-forming bacteria determine preservation or decay in the first steps toward fossilization of marine embryos. Evol. Develop . 15, 243-256.

Rickard, D., \& Luther, G.W. (2007). Chemistry of Iron Sulfides.Chem. Rev. 107 , 514-562.

Rozalén, M.L., Huertas, F.J., Brady, P.V., Cama, J., García-Palma, S., \& Linares, J. (2008). Experimental study of the effect of $\mathrm{pH}$ on the kinetics of montmorillonite dissolution at $25^{\circ} \mathrm{C}$. Geochim. et Cosmochim. Acta . 72, 4224-4253.

Sadiq, M.F. (1995). Effect of sodium azide and trifluoperazine on growth, development and monolayer cell differentiation inDictyostelium discoideum. J. of Biosci . 20 , 481-491.

Sagemann, J., Bale, S.L., Briggs, D.E.G., \& Parkes, R.J. (1999). Controls on the formation of authigenic minerals in association with decaying organic matter: an experimental approach. Geochim. et Cosmochim. Acta . 63 , 1083-1095.

Schiffbauer, J.D., Xiao, S., Cai, Y., Wallace, A.F., Hua, H. et al. (2014). A unifying model for NeoproterozoicPalaeozoic exceptional fossil preservation through pyritization and carbonaceous compression. Nat. Commun . 5,5754 .

Schopf, W.J. (1976). Are the oldest 'fossils', fossils? Origins of life . 7 , 19-36.

Seymour, G.B., Tucker, G., \& Leach, L.A. (2004). Cell Adhesion Molecules in Plants and Animals. Biotechnol. Gen. Engineering Rev . 21, 123-132.

Sharpe, S.C., Eme, L., Brown, M.W., \& Roger, A.J. (2015). Timing the Origins of Multicellular Eukaryotes Through Phylogenomics and Relaxed Molecular Clock Analyses. In Evolutionary Transitions to Multicellular Life. 2 (ed. Ruiz-Trillo, I., Nedelcu, A.) 3-29 (Dordrecht: Springer).

Siveter, D.J., Briggs, D.E.G., Siveter, D.J., \& Sutton, M.D. (2020). The Herefordshire Lagerstätte: fleshing out Silurian marine life.J. Geol. Soc . 177, 1-13.

Siu, C.H., Sriskanthadevan, S., Wang, J., Hou, L., Chen, G. et al. (2011). Regulation of spatiotemporal expression of cell-cell adhesion molecules during development of Dictyostelium discoideum .Development, Growth, Differentiation . 53, 518-527.

Sotomayor, M., \& Schulten, K. (2008). The allosteric role of the $\mathrm{Ca}^{++}$switch in adhesion and plasticity of C-cadherin.Biophysical J. 94, 4621-4633.

Strang, K.M., Armstrong, H.A., Harper, D.A.T., \& Trabucho-Alexandre, J.P. (2016). The Sirius Passet Lagerstätte: silica death masking opens the window on the earliest mat ground community of the Cambrian explosion. Lethaia . 49 , 631-643.

Wilson, L.A., \& Butterfield, N.J. (2014). Sediment effects on the preservation of Burgess Shale-type compression fossils. Palaios .29 , 145-154. 
Zhu, Q., Aller, R.C., \& Fan, Y. (2006). Two-dimensional pH distributions and dynamics in bioturbated marine sediments. Geochim. et Cosmochim. Acta . 70 , 4933-4949.

\section{TABLES}

Table 1. Taphonomic experiments with Artemia salinaburied in different sediments.

\begin{tabular}{lll}
\hline Sediment & Duration & Task \\
\hline Mg-chlorite (clinochlore) in ASW* & 12 months & To test decay rate, mineralogical transformations of the sediment, elemen \\
Fe-chlorite (chamosite) in ASW & 12 months & \\
Kaolinite in ASW & 12 months & To test decay rate, mineralogical transformations, composition of the car \\
Artificial $\mathrm{SiO}_{2}$ in ASW & 12 months & To test decay rate, composition of the carcasses; influence of silicon \\
Montmorillonite in fresh water & 5 years & To test decay rate, mineralogical transformations, composition of the car \\
Sediment-free control in ASW & 12 months & To test decay rate and composition of the carcasses with and without sed \\
\hline
\end{tabular}

* ASW - artificial sea water (see Materials and Methods for its chemical composition)

Table 2 . Initial chemical composition of the experimental sediments (measured by X-ray fluorescent analysis; calculated as oxides wt\%).

\begin{tabular}{|c|c|c|c|c|c|c|c|c|c|c|}
\hline $\begin{aligned} & \mathrm{CO}_{2} \\
& \text { Elements }(\%)\end{aligned}$ & $\begin{array}{l}\mathrm{Na}_{2} \mathrm{O} \\
(\%)\end{array}$ & $\begin{array}{l}\mathrm{MgO} \\
(\%)\end{array}$ & $\begin{array}{l}\mathrm{Al}_{2} \mathrm{O}_{3} \\
(\%)\end{array}$ & $\begin{array}{l}\mathrm{SiO}_{2} \\
(\%)\end{array}$ & $\begin{array}{l}\mathrm{K}_{2} \mathrm{O} \\
(\%)\end{array}$ & $\begin{array}{l}\mathrm{CaO} \\
(\%)\end{array}$ & $\begin{array}{l}\mathrm{TiO}_{2} \\
(\%)\end{array}$ & $\begin{array}{l}\mathrm{MnO} \\
(\%)\end{array}$ & $\begin{array}{l}\mathrm{Fe}_{2} \mathrm{O}_{3} \\
(\%)\end{array}$ & $\begin{array}{l}\mathrm{P}_{2} \mathrm{O}_{5} \\
(\%)\end{array}$ \\
\hline \multicolumn{11}{|l|}{$\begin{array}{l}\text { Sample } \\
\text { name }\end{array}$} \\
\hline Clinochlor£2.11 & $<0.02$ & 30.33 & 20.74 & 27.03 & $<0.02$ & 0.22 & 0.59 & 0.104 & 8.63 & 0.16 \\
\hline Chamosite9.99 & 0.04 & 1.13 & 17.43 & 23.40 & 0.01 & 0.40 & 9.95 & 0.15 & 37.12 & 0.18 \\
\hline Kaolinite 13.95 & $<0.1$ & 0.21 & 36.83 & 45.81 & 0.49 & 0.35 & 0.84 & $<0.01$ & 1.31 & 0.03 \\
\hline Montmorilldnote & 1.35 & 1.96 & 10.52 & 71.65 & 0.25 & 0.59 & 0.1 & 0.06 & 1.96 & 0.01 \\
\hline $\begin{array}{l}\text { Artificial } 10.3 \\
\mathrm{SiO}_{2}\end{array}$ & 0.7 & 0.01 & 0,01 & 88.92 & 0.06 & 0.01 & 0 & 0 & 0.01 & 0 \\
\hline $\begin{array}{l}\text { Artificial } 0 \\
\text { sea } \\
\text { water }\end{array}$ & 24 & 7.19 & 0.02 & 0.02 & 3.80 & 2.71 & 0 & 1.60 & 0 & 0 \\
\hline
\end{tabular}

Table 3. Degree of preservation of A. salina nauplii in different sediments (percentage of preservational groups).

\begin{tabular}{lll}
\hline Preservational groups & Group 1 & Group 2 \\
\hline Morphology / sediment & All limbs, gut and body shape well preserved & All limbs and body shape well preserved, no trace \\
Kaolinite & 17.5 & 42.3 \\
Montmorillonite & 21.3 & 49.8 \\
Artificial $\mathrm{SiO}_{2}$ & 30.25 & 13.5 \\
Chamosite & 15.9 & 13.6 \\
Clinochlore & 5.12 & 17.2 \\
Artificial sea water & 6.3 & 1.25 \\
\hline
\end{tabular}

Table 4. $\mathrm{pH}$ in the different layers of experimental sediments with A. salina nauplii (A.s.) and controls without nauplii. Local maxima at water/sediment interface are shown in bold. Each number represents the 
results of three measurements; intervals are shown if these results were different.

\begin{tabular}{lllll}
\hline Sediment & Initial pH of water & Water column & Interface water/sediment & Sediment (middle part) \\
\hline Kaolinite + A.s. & 7.8 & 7.76 & $\mathbf{7 . 0 4}, \mathbf{7 . 1 3}$ & 6.05 \\
Kaolinite control & 7.8 & 7.5 & 7.7 & 7.9 \\
Art. $\mathrm{SiO}_{2}+$ A.s. & 7.8 & $8.20-8.25$ & $\mathbf{8 . 3 5 - 8 . 4 4}$ & $7.78-7.80$ \\
Art. $\mathrm{SiO}_{2}$ control & 7.8 & $7.71-7.81$ & $\mathbf{8 . 6}$ & $7.70-7.76$ \\
Clinochlore + A.s. & 7.8 & 8.7 & $\mathbf{8 . 8 0 - 8 . 9 2}$ & $8.17-8.22$ \\
Clinochlore control & $7.4-7.8$ & $7.1-7.4$ & $6.22-6.45$ & $5.9-7.3$ \\
Chamosite + A.s. & 7.8 & 8.48 & $7.00-7.04$ & $6.83-6.91$ \\
Chamosite control & 7.8 & $8.05-8.07$ & 7.4 & $7.09-7.11$ \\
Montmorillonite + A.s. & 7.0 & $9.63-9.70^{* *}$ & $9.77-10.1^{* * *}$ & $10.9-11.0^{* * * *}$ \\
\hline
\end{tabular}

*7.04 immediately above the sediment, 7.13 in the topmost sediment.

**topmost part of the red layer; ${ }^{* * *}$ middle of the red layer; **** $2 \mathrm{~cm}$ above the bottom (see Figure $1 \mathrm{M}$ )

Table 5. Elemental composition of the exhumed carcasses and sediment particles: SEM/EDX point analysis (at $15 \mathrm{keV}$, on copper support). Content of the elements is shown (wt\% as oxides) in the exhumed and rinsed nauplii (Body) and in the adhered sediment particles (Particles). See examples of the points in Figure 5.

\begin{tabular}{|c|c|c|c|c|c|c|c|c|c|}
\hline Sediment & Location & Point \# & $\mathrm{CO}_{2}$ & $\mathrm{MgO}$ & $\mathrm{SiO}_{2}$ & $\mathrm{Al}_{2} \mathrm{O}_{3}$ & $\mathrm{FeO}$ & $\mathrm{CaO}$ & $\mathrm{Cl}$ \\
\hline \multirow[t]{6}{*}{ Kaolinite } & \multirow[t]{3}{*}{ Body } & 1 & 25.02 & 0 & 1.7 & 1.65 & 0 & 1.14 & 0 \\
\hline & & 2 & 26.09 & 0 & 0.69 & 0.73 & 0 & 0.77 & 0.47 \\
\hline & & $\Sigma / \nu$ & 25.55 & 0 & 1.19 & 1.19 & $\mathbf{0}$ & 0.95 & 0.24 \\
\hline & \multirow[t]{3}{*}{ Particles } & 1 & 22.51 & 0.19 & 3.59 & 3.35 & 0 & 1.92 & 0.52 \\
\hline & & 2 & 20.65 & 0 & 5.65 & 5.39 & 0 & 1.28 & 0.19 \\
\hline & & $\Sigma / \nu$ & 21.58 & 0.10 & 4.62 & 4.37 & $\mathbf{0}$ & 1.60 & 0.35 \\
\hline \multirow[t]{23}{*}{ ArtificIalsilica } & \multirow[t]{15}{*}{ Body } & 1 & 23.48 & 0.41 & 4.00 & 0.30 & 0 & 0 & 4.14 \\
\hline & & 2 & 26.07 & 0.15 & 1.28 & 0 & 0 & 0.09 & 1.35 \\
\hline & & 3 & 24.73 & 0.23 & 2.48 & 0.25 & 0 & 0.36 & 2.75 \\
\hline & & 4 & 23.64 & 0.41 & 4.72 & 0.07 & 0 & 0.23 & 2.18 \\
\hline & & 5 & 24.47 & 0.35 & 3.41 & 0 & 0 & 0.10 & 2.31 \\
\hline & & 6 & 23.80 & 0.35 & 4.09 & 0 & 0 & 0.61 & 2.60 \\
\hline & & 7 & 25.61 & 0.41 & 0.31 & 0 & 0 & 2.80 & 0.91 \\
\hline & & 8 & 26.44 & 0.10 & 0.13 & 0 & 0 & 1.77 & 0.23 \\
\hline & & 9 & 25.76 & 0.27 & 0.28 & 0 & 0 & 2.57 & 0.95 \\
\hline & & 10 & 26.42 & 0.18 & 0.16 & 0 & 0 & 1.16 & 0.95 \\
\hline & & 11 & 26.96 & 0.05 & 0.10 & 0 & 0 & 0.42 & 0.33 \\
\hline & & 12 & 26.97 & 0.08 & 0.13 & 0 & 0 & 0.40 & 0.23 \\
\hline & & 13 & 26.95 & 0.09 & 0.09 & 0 & 0 & 0.47 & 0.24 \\
\hline & & 14 & 26.46 & 0.15 & 0.09 & 0 & 0 & 1.45 & 0.57 \\
\hline & & $\Sigma / \nu$ & 25.55 & 0.23 & 1.52 & 0.04 & 0 & 0.89 & 1.41 \\
\hline & \multirow[t]{8}{*}{ Particles } & 1 & 18.32 & 1.02 & 12.86 & 0.06 & 0 & 0.20 & 2.95 \\
\hline & & 2 & 17.75 & 0.72 & 14.57 & 0.17 & 0 & 0.21 & 1.98 \\
\hline & & 3 & 19.43 & 0.86 & 10.77 & 0.06 & 0 & 0.75 & 2.85 \\
\hline & & 4 & 21.30 & 0.85 & 6.69 & 0.06 & 0 & 0.39 & 5.18 \\
\hline & & 5 & 24.64 & 0.43 & 0.83 & 0.29 & 0 & 0.26 & 6.32 \\
\hline & & 6 & 18.37 & 0.83 & 6.94 & 0 & 0 & 0.74 & 10.14 \\
\hline & & 7 & 18.39 & 1.51 & 8.43 & 0 & 0 & 1.16 & 8.31 \\
\hline & & 8 & 20.07 & 0.83 & 4.17 & 0 & 0 & 0.45 & 9.37 \\
\hline
\end{tabular}




\begin{tabular}{|c|c|c|c|c|c|c|c|c|c|}
\hline Sediment & Location & Point \# & $\mathrm{CO}_{2}$ & $\mathrm{MgO}$ & $\mathrm{SiO}_{2}$ & $\mathrm{Al}_{2} \mathrm{O}_{3}$ & $\mathrm{FeO}$ & $\mathrm{CaO}$ & $\mathrm{Cl}$ \\
\hline & & 9 & 17.99 & 0.49 & 10.04 & 0.27 & 0 & 0.16 & 7.02 \\
\hline & & 10 & 22.00 & 0.43 & 7.12 & 0 & 0 & 0.46 & 2.83 \\
\hline & & 11 & 13.53 & 0.28 & 20.03 & 0 & 0 & 0.09 & 4.62 \\
\hline & & 12 & 10.35 & 0.33 & 25.30 & 0 & 0 & 0.22 & 4.49 \\
\hline & & 13 & 13.93 & 0.33 & 19.49 & 0.20 & 0 & 0.39 & 4.28 \\
\hline & & 14 & 17.41 & 0.32 & 13.47 & 0.10 & 0 & 0.22 & 4.24 \\
\hline & & 15 & 15.94 & 0.34 & 16.62 & 0 & 0 & 0.35 & 3.45 \\
\hline & & $\Sigma / \nu$ & 17.96 & 0.64 & 11.82 & 0.08 & $\mathbf{0}$ & 0.40 & 5.20 \\
\hline \multirow[t]{17}{*}{ Montmorillonite } & Body & 1 & 38.31 & 0 & 6.60 & 2.11 & 0 & 0 & 0.61 \\
\hline & & 2 & 39.12 & 0 & 6.84 & 2.37 & 0 & 0 & 0.71 \\
\hline & & 3 & 36.27 & 0.65 & 10.66 & 3.22 & 0.90 & 0.40 & 0.32 \\
\hline & & 4 & 47.12 & 0 & 2.56 & 1.31 & 0 & 0 & 0 \\
\hline & & 5 & 46.48 & 0 & 3.59 & 1.35 & 0 & 0 & 0 \\
\hline & & 6 & 37.01 & 0.73 & 10.76 & 3.03 & 0 & 0.43 & 0.51 \\
\hline & & 7 & 51.04 & 0 & 2.39 & 1.30 & 0 & 0.81 & 1.46 \\
\hline & & 8 & 39.91 & 0.70 & 5.63 & 1.95 & 0 & 0 & 0.61 \\
\hline & & 9 & 51.61 & 0 & 2.14 & 1.16 & 0 & 0 & 1.05 \\
\hline & & 10 & 50.91 & 0 & 1.45 & 0.51 & 0 & 0 & 0.41 \\
\hline & & $\Sigma / \nu$ & 43.78 & 0.21 & 5.26 & 1.83 & 0.09 & 0.16 & 0.57 \\
\hline & Particles & 1 & 12.01 & 0.81 & 26.94 & 4.70 & 0.85 & 0.74 & 0.21 \\
\hline & & 2 & 9.28 & 0.98 & 28.35 & 5.27 & 1.09 & 0.73 & 0.21 \\
\hline & & 3 & 9.10 & 0.98 & 28.11 & 4.95 & 0.92 & 0.74 & 0.29 \\
\hline & & 4 & 10.38 & 0.79 & 27.13 & 4.36 & 1.34 & 0.94 & 0 \\
\hline & & 5 & 8.73 & 0.89 & 25.62 & 4.43 & 0.68 & 0.68 & 0.17 \\
\hline & & $\Sigma / \nu$ & 9.90 & 0.89 & 27.23 & 4.74 & 0.98 & 0.77 & 0.22 \\
\hline \multirow[t]{25}{*}{ Chamosite } & Body & 1 & 74.13 & 0 & 0 & 0.32 & 2.28 & 1.47 & 0 \\
\hline & & 2 & 71.34 & 0 & 0 & 0.32 & 0.94 & 2.20 & 0 \\
\hline & & 3 & 69.87 & 0 & 0 & 0 & 1.31 & 2.44 & 0 \\
\hline & & 4 & 64.22 & 0.26 & 0.94 & 0.88 & 2.19 & 0.26 & 0.30 \\
\hline & & 5 & 69.51 & 0 & 0 & 0 & 0.77 & 0.46 & 0 \\
\hline & & 6 & 72.93 & 0 & 0.72 & 0 & 0.78 & 0.66 & 0 \\
\hline & & 7 & 73.15 & 0 & 0 & 0 & 0.67 & 0.33 & 0.37 \\
\hline & & 8 & 65.29 & 0 & 0 & 0 & 1.44 & 0.50 & 0 \\
\hline & & 9 & 69.23 & 0 & 0 & 0 & 1.20 & 2.29 & 0 \\
\hline & & 10 & 59.59 & 0 & 0 & 0 & 2.42 & 0.47 & 0 \\
\hline & & $\Sigma / \nu$ & 68.90 & 0.03 & 0.17 & 0.15 & 1.40 & 1.10 & 0.07 \\
\hline & Particles & 1 & 13.37 & 0.47 & 12.13 & 10.68 & 15.10 & 0.49 & 0 \\
\hline & & 2 & 14.67 & 0.53 & 6.58 & 5.68 & 13.66 & 0.40 & 0.20 \\
\hline & & 3 & 12.33 & 0.31 & 7.92 & 7.43 & 13.45 & 0.33 & 0 \\
\hline & & 4 & 16.16 & 0.34 & 6.60 & 6.05 & 13.32 & 0.64 & 0.39 \\
\hline & & 5 & 24.31 & 0.36 & 3.94 & 3.49 & 8.45 & 0.54 & 0.25 \\
\hline & & 6 & 15.26 & 0.42 & 4.51 & 4.88 & 18.26 & 0.19 & 0.17 \\
\hline & & 7 & 22.62 & 0.64 & 6.18 & 5.42 & 9.31 & 0.20 & 0.16 \\
\hline & & 8 & 26.65 & 0.44 & 5.78 & 4.84 & 10.76 & 0.53 & 0 \\
\hline & & 9 & 13.63 & 0.73 & 9.59 & 8.09 & 10.02 & 0.12 & 0 \\
\hline & & 10 & 17.08 & 0.40 & 6.82 & 5.18 & 9.28 & 0.11 & 0.30 \\
\hline & & 11 & 19.68 & 0.40 & 4.88 & 4.81 & 5.04 & 0.38 & 0.69 \\
\hline & & 12 & 16.13 & $?$ & 7.61 & 5.12 & 11.38 & 0 & 0 \\
\hline & & 13 & 14.83 & $?$ & 8.34 & 6.63 & 11.73 & 0 & 0 \\
\hline & & 14 & 19.06 & 0.61 & 6.24 & 4.05 & 6.34 & 0 & 0 \\
\hline
\end{tabular}




\begin{tabular}{|c|c|c|c|c|c|c|c|c|c|}
\hline Sediment & Location & Point \# & $\mathrm{CO}_{2}$ & $\mathrm{MgO}$ & $\mathrm{SiO}_{2}$ & $\mathrm{Al}_{2} \mathrm{O}_{3}$ & $\mathrm{FeO}$ & $\mathrm{CaO}$ & $\mathrm{Cl}$ \\
\hline & & 15 & 15.55 & 0.46 & 7.43 & 6.34 & 10.86 & 0.30 & 0 \\
\hline & & $\Sigma / \nu$ & 17.42 & 0.41 & 6.95 & 6.00 & 11.13 & 0.28 & 0.14 \\
\hline \multirow[t]{36}{*}{ Clinochlore } & Body & 1 & 27.23 & 0 & 0 & 0 & 0 & 0.16 & 0 \\
\hline & & 2 & 26.28 & 0.76 & 0.53 & 0.51 & 0 & 0.25 & 0 \\
\hline & & 3 & 26.31 & 0.74 & 0.40 & 0.36 & 0 & 0.39 & 0 \\
\hline & & 4 & 26.96 & 0.13 & 0 & 0.09 & 0 & 0.24 & 0.13 \\
\hline & & 5 & 27.14 & 0 & 0 & 0 & 0 & 0.40 & 0 \\
\hline & & 6 & 26.18 & 0.78 & 0.33 & 0.24 & 0 & 0.76 & 0 \\
\hline & & 7 & 26.8 & 0.26 & 0.10 & 0 & 0 & 0.42 & 0 \\
\hline & & 8 & 26.36 & 0.47 & 0.47 & 0 & 0 & 0.67 & 0 \\
\hline & & 9 & 27.11 & 0.13 & 0 & 0 & 0 & 0.31 & 0 \\
\hline & & 10 & 26.4 & 0.60 & 0.28 & 0.25 & 0.18 & 0.45 & 0 \\
\hline & & 11 & 27.29 & 0 & 0 & 0 & 0 & 0 & 0 \\
\hline & & 12 & 26.24 & 0.78 & 0.43 & 0.31 & 0 & 0.45 & 0 \\
\hline & & 13 & 27.01 & 0.11 & 0 & 0 & 0 & 0.30 & 0 \\
\hline & & 14 & 26.99 & 0.21 & 0.10 & 0.12 & 0 & 0.12 & 0 \\
\hline & & 15 & 26.29 & 0.85 & 0.47 & 0.4 & 0 & 0.12 & 0 \\
\hline & & 16 & 26.40 & 0.51 & 0.33 & 0.28 & 0 & 0.66 & 0 \\
\hline & & 17 & 26.34 & 0.55 & 0.11 & 0 & 0 & 1.24 & 0 \\
\hline & & 18 & 27.11 & 0 & 0 & 0.12 & 0 & 0 & 0 \\
\hline & & 19 & 27.29 & 0 & 0 & 0 & 0 & 0 & 0 \\
\hline & & 20 & 27.07 & 0 & 0 & 0.12 & 0 & 0.17 & 0 \\
\hline & & 21 & 27.29 & 0 & 0 & 0 & 0 & 0 & 0 \\
\hline & & 22 & 26.9 & 0 & 0 & 0 & 0 & 0.81 & 0 \\
\hline & & 23 & 27.14 & 0 & 0 & 0 & 0 & 0.40 & 0 \\
\hline & & 24 & 26.93 & 0.08 & 0 & 0.08 & 0 & 0.19 & 0 \\
\hline & & 25 & 26.81 & 0 & 0.21 & 0 & 0 & 0.60 & 0 \\
\hline & & $\Sigma / \nu$ & 26.79 & 0.28 & 0.15 & 0.11 & 0 & 0.36 & 0 \\
\hline & Particles & 1 & 10.61 & 13.09 & 8.84 & 7.91 & 3.71 & 0.58 & 0 \\
\hline & & 2 & 18.14 & 8.20 & 4.44 & 4.31 & 1.47 & 0.29 & 0 \\
\hline & & 3 & 17.99 & 7.79 & 4.58 & 4.15 & 1.99 & 0.25 & 0 \\
\hline & & 4 & 19.81 & 6.62 & 3.89 & 2.95 & 1.33 & 0.20 & 0 \\
\hline & & 5 & 20.55 & 6.07 & 3.47 & 2.91 & 1.33 & 0 & 0 \\
\hline & & 6 & 12.49 & 12.60 & 7.50 & 7.26 & 2.14 & 0.59 & 0 \\
\hline & & 7 & 9.78 & 14.29 & 9.61 & 7.89 & 2.69 & 1.13 & 0 \\
\hline & & 8 & 16.06 & 8.21 & 5.27 & 4.75 & 3.02 & 2.44 & 0 \\
\hline & & 9 & 7.29 & 14.87 & 10.54 & 8.89 & 4.26 & 0.96 & 0 \\
\hline & & $\Sigma / \nu$ & 14.75 & 10.19 & 6.45 & 5.67 & 2.44 & 0.71 & 0 \\
\hline \multirow[t]{12}{*}{ Artificial sea water } & Body & 1 & 26.03 & 0 & 0 & 0 & 0 & 2.02 & 0.52 \\
\hline & & 2 & 26.76 & 0 & 0 & 0 & 0 & 1.18 & 0.08 \\
\hline & & 3 & 27.01 & 0 & 0 & 0.05 & 0 & 0.29 & 0.07 \\
\hline & & 4 & 21.10 & 0 & 0 & 0 & 0 & 11.57 & 1.64 \\
\hline & & 5 & 26.98 & 0 & 0 & 0 & 0 & 0.40 & 0.14 \\
\hline & & 6 & 22.02 & 1.94 & 0 & 0 & 0 & 3.37 & 0.06 \\
\hline & & 7 & 27.16 & 0 & 0 & 0 & 0 & 0.26 & \\
\hline & & 8 & 24.95 & 0.84 & 0 & 0 & 0 & 1.35 & 0.19 \\
\hline & & 9 & 27.11 & 0 & 0 & 0 & 0 & 0.42 & 0 \\
\hline & & 10 & 27.11 & 0 & 0 & 0 & 0 & 0.40 & 0 \\
\hline & & 11 & 27.00 & 0 & 0 & 0 & 0 & 0.69 & 0 \\
\hline & & 12 & 27.07 & 0 & 0 & 0 & 0 & 0.59 & 0 \\
\hline
\end{tabular}




\begin{tabular}{|c|c|c|c|c|c|c|c|c|c|}
\hline Sediment & Location & Point \# & $\mathrm{CO}_{2}$ & $\mathrm{MgO}$ & $\mathrm{SiO}_{2}$ & $\mathrm{Al}_{2} \mathrm{O}_{3}$ & $\mathrm{FeO}$ & $\mathrm{CaO}$ & $\mathrm{Cl}$ \\
\hline & & $\Sigma / \nu$ & 25.86 & 0.23 & 0 & 0 & 0 & 1.88 & 0.25 \\
\hline
\end{tabular}

\section{FIGURE LEGENDS}

Figure 1. Taphonomic (burial) experiments: Experimental and control tubes with sediments and buried Artemia salina. A, B, C - chamosite: A, control without A. salina ; B, sediment with A. salina after 12 months. The black layer contains numerous carcasses, the orange top layer is comprised of carcasses covered by some iron species. C, enlarged area (framed in B) showing spots around nauplii. D, E, F - clinochlore: the same as the previous triplet; multiple light spots around the carcasses are well visible. G, H, I - kaolinite: complex light spots around the carcasses are visible. J, K, L - artificial $\mathrm{SiO}_{2}$; orange coloration marks the layer in which the carcasses accumulated. $\mathrm{M}$ - montmorillonite after 5 months. The red layer is well visible; orange and brownish spots (below the red layer) and the orange layer at the bottom are carcasses.

Figure 2. Nauplii of A. salina from different sediments (SEM images, except B). A - well-preserved specimen with limbs and gut (preservational group 1) from the montmorillonite. B, B' - specimens from the montmorillonite that remained wrapped in clay envelopes after rinsing. C - nauplius from the ASW control with poorly preserved, shapeless body (preservational group 3). D - nauplius from artificial silica, preservational group 2 (overall body shape and limbs preserved, no internal anatomy). E-group 1 specimen from the kaolinite. $\mathrm{F}$ - perfectly preserved filter apparatus on antenna 2 of a specimen from the montmorillonite. $\mathrm{G}$ - the bases of antenna 2 chaetae with tightly adhered small mineral particles (magnified framed area from $\mathrm{E}$, rotated $90^{\circ}$ clockwise). Scale bars $200 \mu \mathrm{m}$ (A - E), $3 \mu \mathrm{m}$ (F, G).

Figure 3. Biochemical composition of the carcasses: FT-IR spectra for specimens from the sediments and controls. A - an example of a well preserved specimen (group 1; buried in montmorillonite for 5 years; scale bar $100 \mu \mathrm{m}$ ). B - an example of a poorly preserved specimen (group 4; buried for 1 year in kaolinite; scale bar $100 \mu \mathrm{m}$ ). C - FT-IR of the live control (freshly killed nauplii) and the ASW control. D - wavelength interval containing chitin characteristic bands (gray shadow) in carcasses from all sediments. E - wavelength interval containing proteins characteristic bands (gray shadow) in carcasses from all sediments. F - montmorillonite hosted carcasses (5 years) and corresponding sediment particles; wavelength interval characteristic for the montmorillonite shown in pink shadow; $\mathrm{G}$ - the same for the clinochlore. In F and $\mathrm{G}$, red lines are carcasses spectra, blue lines are sediment spectra. $\mathrm{H}$ - one-day control in kaolinite and the corresponding kaolinite particles.

Figure 4. Biochemical composition of the carcasses: FT-IR spectra for the best and worst preserved specimens from the kaolinite. Red line - preservational groups 1 and 2 (best preserved specimens), blue line - groups 4 and 5 (worst preserved specimens).

Figure 5. Example of a body surface fragment with points suitable for SEM/EDX analysis of the body (white asterisks) and sediment particles (black asterisks). The carcass is from the chamosite. Bacterial cocci are also visible. Scale bar $4 \mu \mathrm{m}$.

Figure 6. Elemental content of the body tissues and adhered sediment particles. Data from SEM/EDX analysis (Table 5). A - Absolute elemental content (average weight percentage) of the body tissues. Aluminium and silicon are increased in the carcasses from the montmorillonite, kaolinite and silica (the three sediments that ensure good preservation). The degree of preservation (Table 3) is shown on the lower diagram. Sediments with better preservation are depicted in capital letters on the horizontal axis. B - Relative elemental content: Body tissues relative to adhered sediment particles, normalised by silicon: ([Element in body $] /[$ Silicon in body] $) /([$ Element in particles] /[Silicon in particles $])$. This ratio shows the extent to which the element enters the carcasses after being dissolved from the sediment.

Figure 7. Results of Simultaneous Thermal Analysis (STA) for montmorillonite (A) and chamosite (B). Green lines - experimental sediments, red lines - control sediments without Artemia salina . New peak 
at $354^{\circ} \mathrm{C}$ of ferrihydrite (Földvári, 2011) and shift in endoeffect to $660.7^{\circ} \mathrm{C}$ shown in A indicate structural disintegration of the montmorillonite. Shift of the first endoeffect from 96.7 to $105^{\circ} \mathrm{C}$ shown in B indicates accumulation of amorphous phase in the chamosite; shift of the second endoeffect from 513 to $530^{\circ} \mathrm{C}$ marks leaching of iron from the brucite layer; higher exoeffect $829^{\circ} \mathrm{C}$ (in comparison with $813^{\circ}$ in the control sediment) indicates disintegration of the talc layer of the chamosite.

Figure 8. Samples from chamosite and montmorillonite with iron- and sulphur-rich spherules. A - nauplius from the chamosite (on a copper support) with Fe-S spherules. B - enlarged portion from A showing spherules. D, E - the same from the montmorillonite. Note the spherules (whitish dots) in D scattered all over the surface. C, F - Elemental content of the spherules (SEM/EDX analysis at $20 \mathrm{kEv}$, values are atomic percentages): $\mathrm{C}$ - from the chamosite, $\mathrm{F}$ - from the montmorillonite; $\mathrm{Fe} / \mathrm{S}$ atomic ratio is about 1:3.

Figure 9. Deposition of aluminium on multicellular and unicellular organisms detected by fluorescent dye lumogallion (emission at $488 \mathrm{~nm}$, green). A-C - sponge Spongilla lacustris: A - autofluorescence, B - lumogallion-stained Al-negative control, C - lumogallion-stained Al-positive experiment. D-I - flagellateEuglena gracilis : D - autofluorescence, $\mathrm{E}$ - Al-negative; F - Al-positive; G, H, I, - the same under a confocal microscope to show intracellular localization of the fluorescence-emitting organelles. J-P - social amoeba Dictyostelium discoideum; all samples were stained by cellular Hoechst dye to locate the cells; in each pair or images (e.g., J', J) the first image (in this case, J') shows fluorescence at $409 \mathrm{~nm}$ (Hoechst dye), while the second image (in this case, J) shows fluorescence at $488 \mathrm{~nm}$ (lumogallion). J, L, N - unicellular amoebae; J - "autofluorescence" (Al-negative, no lumogallion staining), L - lumogallion-stained Al-negative control, N - lumogallion-stained Al-positive experiment. K, M, P - multicellular fruiting body; K - "autofluorescence", M - lumogallion-stained Al-negative control, $\mathrm{P}$ - lumogallion-stained Al-positive experiment. O - multicellular culminant, lumogallion-stained Al-positive experiment. Fluorescence is bright green only in Al-positive multicellular stages ( $\mathrm{O}$ and $\mathrm{P}$ ), implying that only multicellular stages absorb aluminium from the medium. Scale bars C-F, K, M, O, P- $100 \mu \mathrm{m}$, G-I, J, L, N-20 $\mu \mathrm{m}$. 

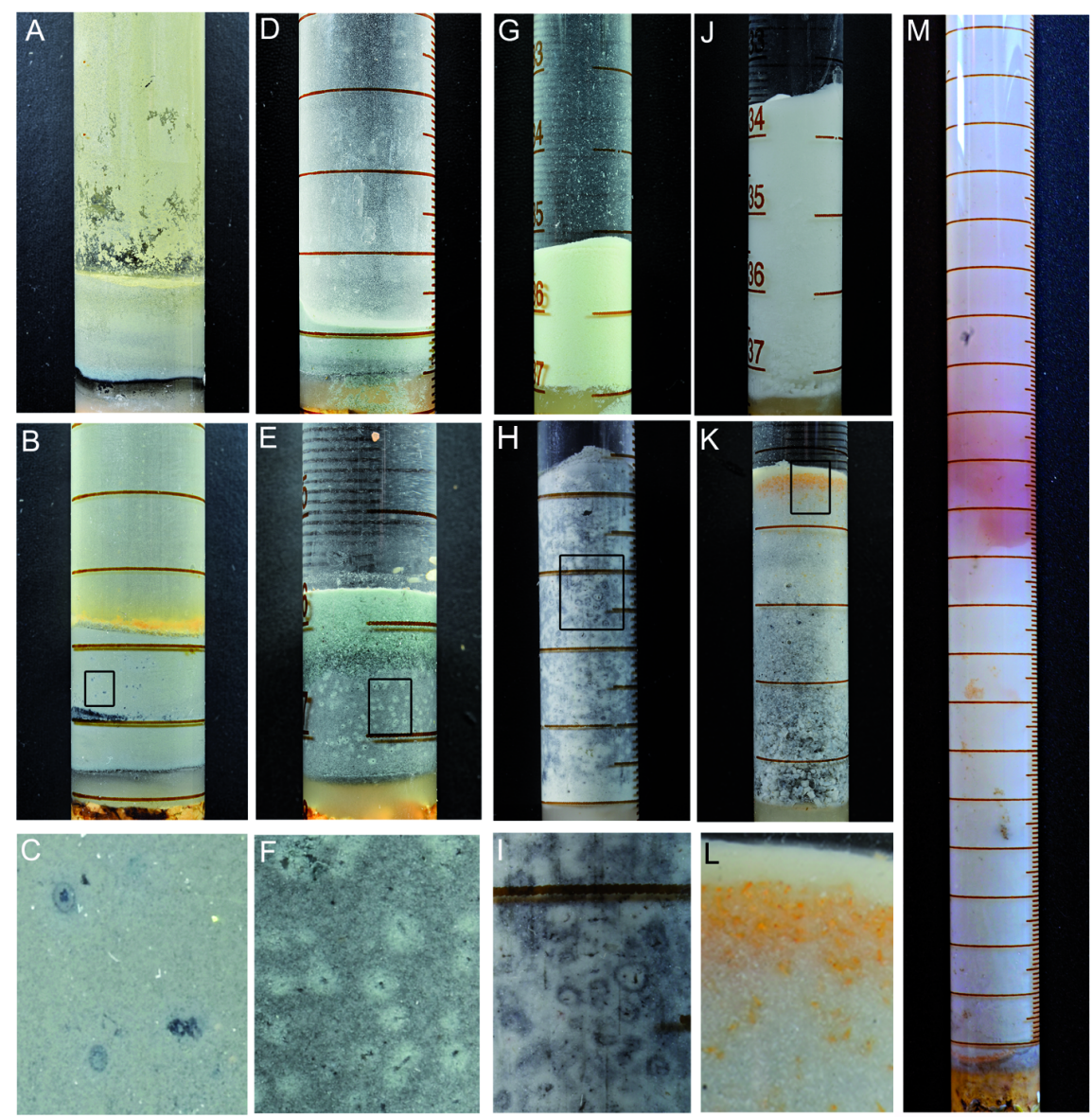

(v) 



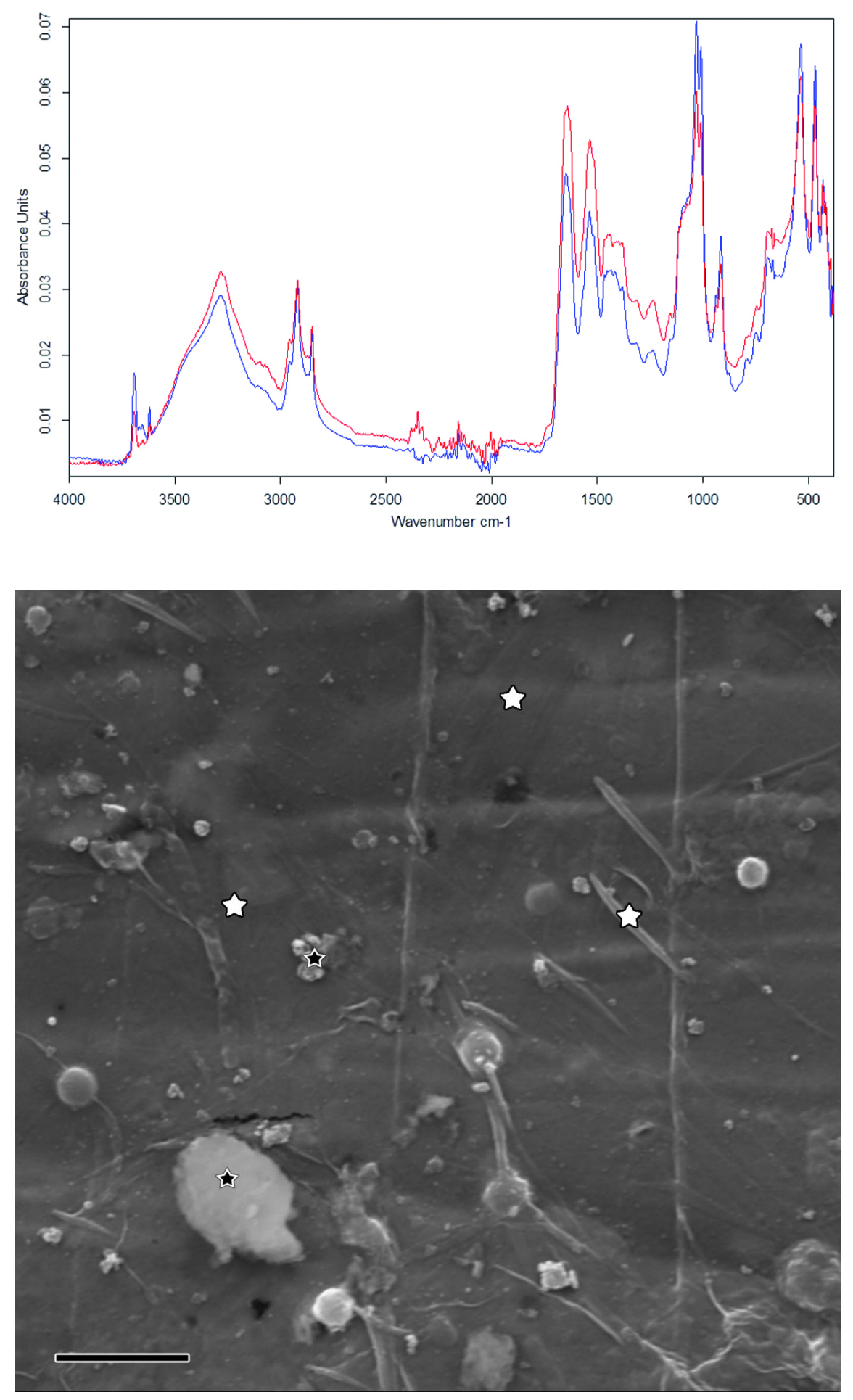

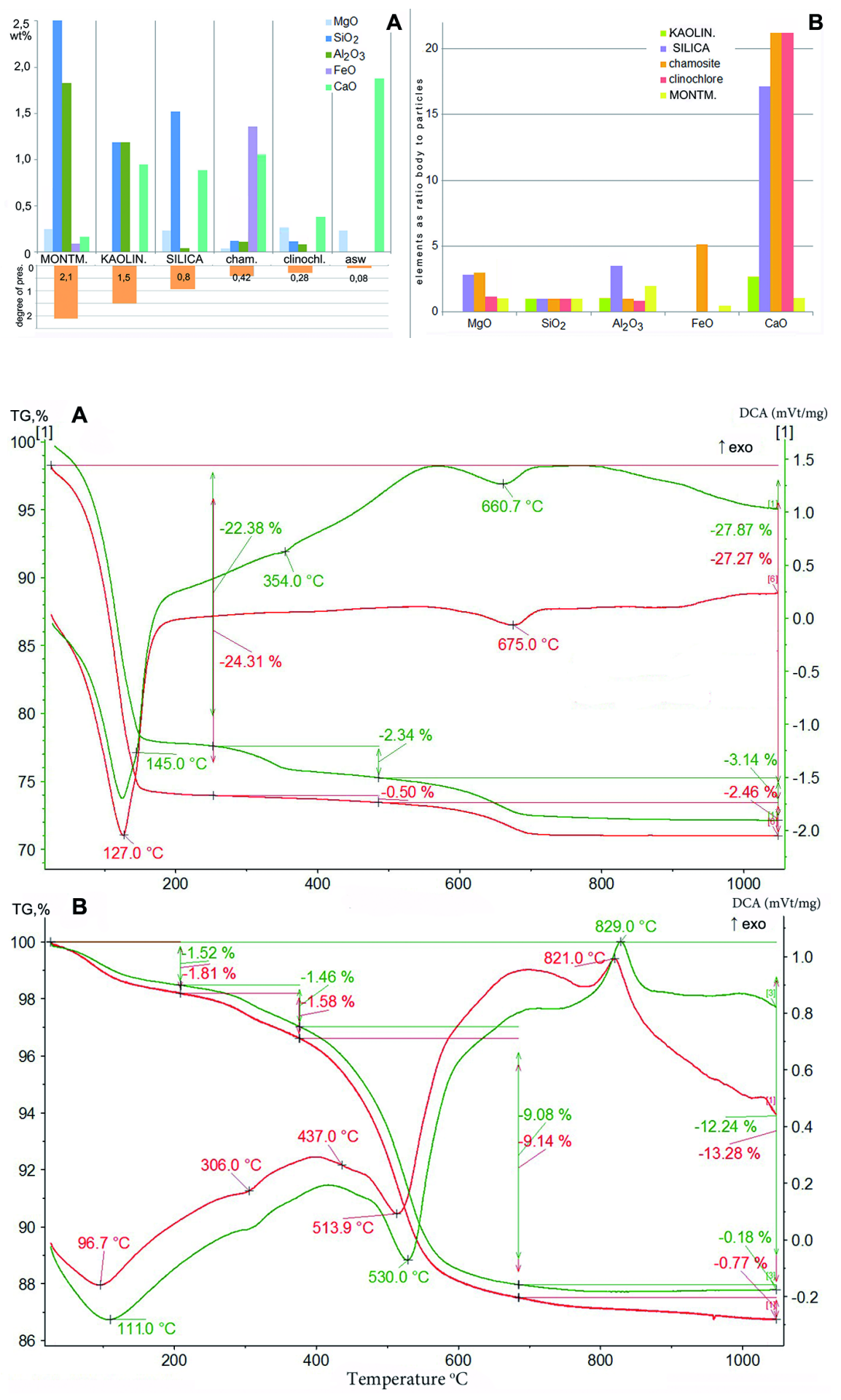

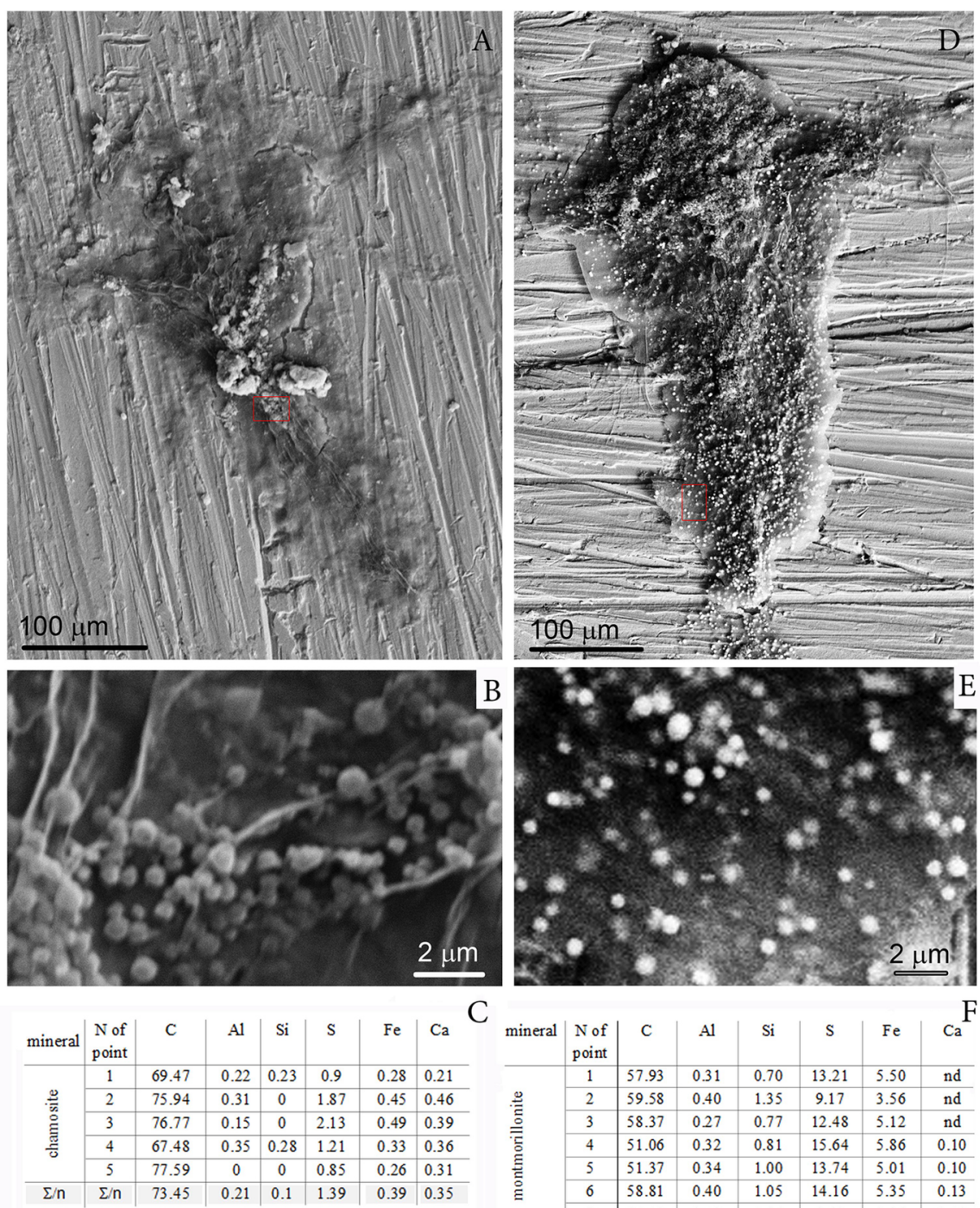

$C$

\begin{tabular}{l|c|c|c|c|c|c|c} 
mineral & $\begin{array}{c}\mathrm{N} \text { of } \\
\text { point }\end{array}$ & $\mathrm{C}$ & $\mathrm{Al}$ & $\mathrm{Si}$ & $\mathrm{S}$ & $\mathrm{Fe}$ & $\mathrm{Ca}$ \\
\hline \multirow{3}{*}{} & 1 & 57.93 & 0.31 & 0.70 & 13.21 & 5.50 & nd \\
\hline \multirow{2}{*}{} & 2 & 59.58 & 0.40 & 1.35 & 9.17 & 3.56 & nd \\
\hline \multirow{2}{*}{} & 3 & 58.37 & 0.27 & 0.77 & 12.48 & 5.12 & nd \\
\hline \multirow{2}{*}{} & 4 & 51.06 & 0.32 & 0.81 & 15.64 & 5.86 & 0.10 \\
\cline { 2 - 8 } & 5 & 51.37 & 0.34 & 1.00 & 13.74 & 5.01 & 0.10 \\
\hline \multirow{2}{*}{} & 6 & 58.81 & 0.40 & 1.05 & 14.16 & 5.35 & 0.13 \\
\hline & 7 & 54.18 & 0.48 & 1.56 & 8.63 & 3.25 & 0.10 \\
\hline & $\sum \mathrm{n}$ & 55.9 & 0.36 & 1.03 & 12.43 & 4.8 & 0.11
\end{tabular}



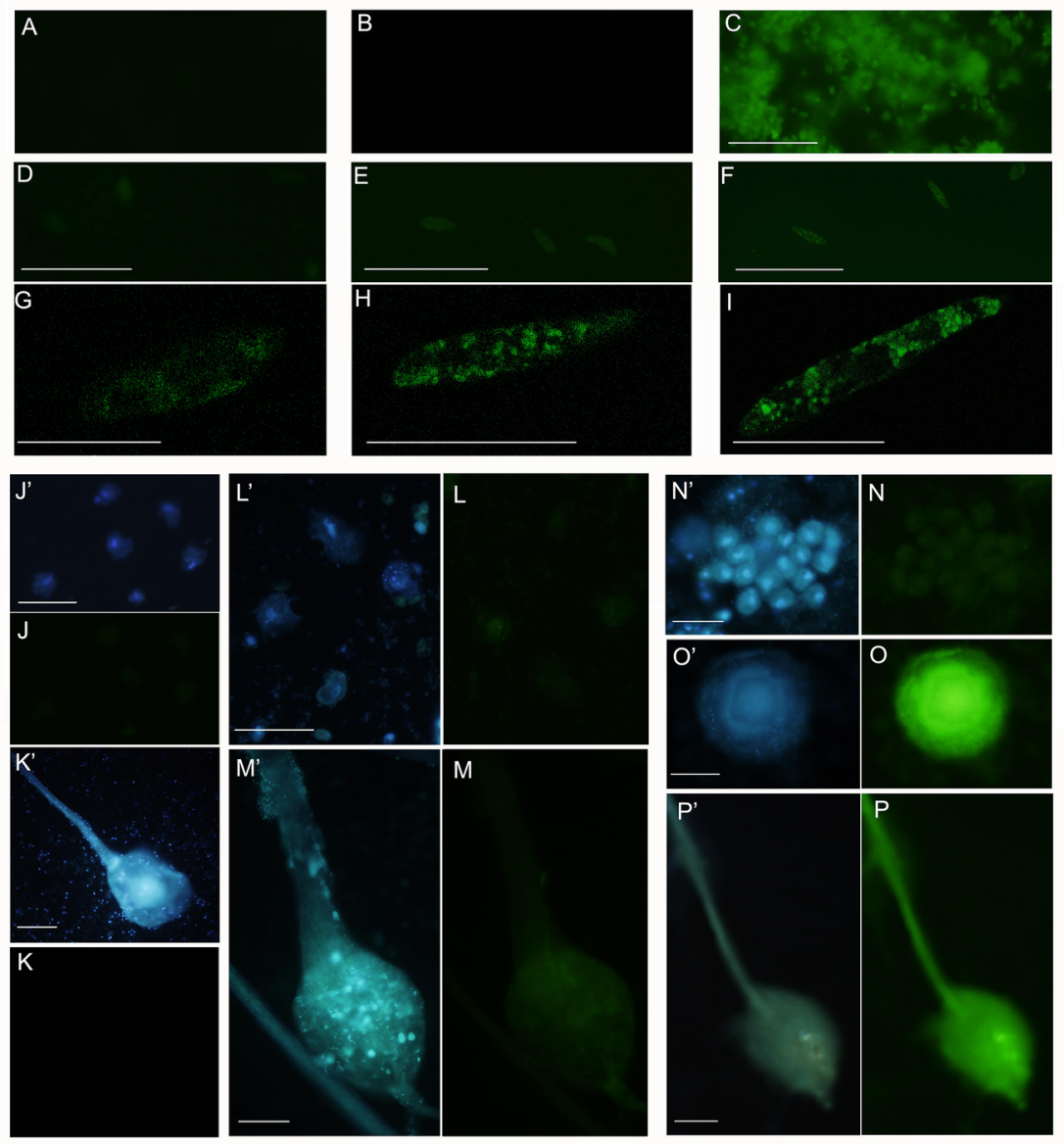